\title{
Implication of haematophagous arthropod salivary proteins in host-vector interactions
}

\author{
Albin Fontaine ${ }^{1}$, Ibrahima Diouf ${ }^{1}$, Nawal Bakkali', Dorothée Missé ${ }^{2}$, Frédéric Pagès ${ }^{3}$, Thierry Fusai ${ }^{1}$, \\ Christophe Rogier ${ }^{1,4}$ and Lionel Almeras ${ }^{1 *}$
}

\begin{abstract}
The saliva of haematophagous arthropods contains an array of anti-haemostatic, anti-inflammatory and immunomodulatory molecules that contribute to the success of the blood meal. The saliva of haematophagous arthropods is also involved in the transmission and the establishment of pathogens in the host and in allergic responses. This survey provides a comprehensive overview of the pharmacological activity and immunogenic properties of the main salivary proteins characterised in various haematophagous arthropod species. The potential biological and epidemiological applications of these immunogenic salivary molecules will be discussed with an emphasis on their use as biomarkers of exposure to haematophagous arthropod bites or vaccine candidates that are liable to improve host protection against vector-borne diseases.
\end{abstract}

\section{Review}

During the course of evolution, haematophagy has arisen many times in disparate arthropod taxa. Between the taxa, this feeding habit has evolved independently over several million years [1,2] leading to morphophysiological differences among haematophagous arthropods. At the molecular level, this is reflected by the existence of a variety of pharmacologically active molecules in arthropod saliva used to face the constraints of vertebrate host haemostasis, inflammation and adaptive immunity [3-5].

The saliva of haematophagous arthropods is also responsible for causing allergic responses in human hosts, which are manifested by cutaneous pruritic wheal-and-flare reactions at the bite site [6,7]. Thus, a high density of haematophagous arthropods can directly affect human populations worldwide due to their presence and physical nuisance $[8,9]$. Beside this direct effect, arthropods can also indirectly affect human health by transmitting pathogens. Indeed, many viral, bacterial, and eukaryotic pathogens have found haematophagous arthropods ideal vectors to accomplish transmission among vertebrates. Usually, a long-lasting co-

\footnotetext{
* Correspondence: almerasl@imtssa.fr

'Unité de Parasitologie - UMR6236 - IFR48, Antenne Marseille de I'Institut de Recherche Biomédicale des Armées (IRBA), Le Pharo, BP 60109, 13262 Marseille Cedex 07, France

Full list of author information is available at the end of the article
}

speciation has led to specific associations between pathogens and vectors [2]. Hence, pathogens often depend on few related species of vectors for transmission (Table 1). Some of these pathogens have even taken advantage of the immunomodulatory properties of haematophagous salivary proteins in order to enhance their infectivity in the vertebrate host $[10,11]$.

Arthropod-borne diseases are a major health problem worldwide. They cause serious impacts on the economy and survival of human populations living mainly in tropical and sub-tropical countries [12-14]. To a lesser extent, human populations in developed countries are also exposed to a variety of vector-borne pathogens [15-17]. Pathogen vaccine and prophylactic drug research have so far produced little to protect individuals from many arthropod-borne diseases. Currently, vaccines are only available for the yellow fever virus [18], the Japanese encephalitis virus [19], the Rift valley fever virus [20] and the tick-borne encephalitis virus [21]. Protection against Plasmodium, the malaria parasites, still relies on the use of prophylactic drugs and is hampered by the escalation of drug-resistance [22].

Thus, the primary mechanism to protect individuals from vector-borne diseases is the prevention of bites from infected arthropods. This can be achieved by a combination of personal protective measures and vector control strategies adapted to vector behaviour [23-26]. These methods have been historically successful in 
Table 1 Taxonomic classification of major vector-borne diseases

\begin{tabular}{|c|c|c|c|}
\hline \multicolumn{3}{|c|}{ Vectors } & \multirow[t]{2}{*}{ Diseases } \\
\hline Order & Family & Genius & \\
\hline \multirow[t]{12}{*}{ Diptera } & Culicidae & Anopheles & Malaria, \\
\hline & & & Lymphatic filariasis \\
\hline & & Culex & West Nile disease \\
\hline & & & Japanese encephalitis \\
\hline & & Aedes & Yellow fever \\
\hline & & & Chikungunya \\
\hline & & & Dengue \\
\hline & Psychodidae & Phlebotomus & Leishmaniasis \\
\hline & & Lutzomyia & \\
\hline & Glossinidae & Glossina & $\begin{array}{l}\text { Human African } \\
\text { Trypanosomiasis }\end{array}$ \\
\hline & Simulidae & Simulium & Onchocerciasis \\
\hline & Tabanidae & Tabanus & Loiasis \\
\hline \multirow[t]{2}{*}{ Hemiptera } & Reduviidae & Triatoma & Chagas disease \\
\hline & & Rhodnius & \\
\hline \multirow[t]{7}{*}{ Ixodida } & Ixodidae & Amblyomma & Rickettsiosis \\
\hline & & & Tularemia \\
\hline & & Ixodes & Lyme disease \\
\hline & & & Babesiosis \\
\hline & & Haemaphysalis & Tularemia \\
\hline & & & Tick borne encephalitis \\
\hline & Argasidae & Ornithodoros & Relapsing fever \\
\hline
\end{tabular}

The taxonomic classification of the major hematophagous arthropod vectors described in the present review is given with their corresponding diseases.

reducing [27-29] or eliminating [30,31] the transmission of some vector-borne diseases. Currently, the effectiveness of anti-vectorial measures and the evaluation of the transmission of arthropod-borne diseases are determined by laboratory bioassay tests [32-35], by measuring the incidence, morbidity or mortality of vector-borne diseases in controlled clinical trials in the field $[36,37]$ or by entomological methods [38,39]. Concerning mosquito-borne diseases, the entomological reference method to measure vector density is by catching landing mosquitoes on humans, which provides a good estimate of the average number of bites per person per day received from one particular vector species [40]. However, in terms of execution and supervision, this method is very laborious and dependent on the skills of the collector. In addition, the deliberate exposure of human volunteers to vectors has raised some ethical issues against this technique. As the human bite rate was shown to vary within small geographic areas [41,42], the results of local catches cannot be extrapolated to larger areas. Additionally, results from the human landing catch performed by adults can be difficult to extrapolate to children. Alternative entomological methods exist to capture medically important haematophagous arthropods, such as carbon dioxide dry ice traps, light traps and odour baited traps (to collect flying dipterans) [43] or the drag-flag method (to collect ticks) [44]. However, these tools do not differentiate anthropophilic from zoophilic arthropods and cannot precisely assess the contact between haematophagous arthropods and host. Hence, the development of new indicators and methods to evaluate the effectiveness of anti-vectorial strategies at the individual level is necessary.

A common feature shared among arthropod vectors is their habit of feeding on blood involving the injection of saliva into the host's skin. One consequence of the injection of salivary proteins is the eliciting of host antibody responses against these pharmacologically active components [45-51]. Such observations suggest that these antigenic components could potentially be used as immunological tools to evaluate individual exposure to arthropod bites.

This present survey is particularly concerned with the current knowledge of antibody responses to the salivary proteins of haematophagous arthropods. Immunogenic salivary proteins of haematophagous arthropods were first studied for their allergenic properties. However, there is strong evidence for their application in improving host protection against some vector-borne diseases and for their use as alternative immunological tools to assess individual exposure to haematophagous arthropod bites. An overview of the pharmacological activity of the main salivary proteins characterised in various haematophagous arthropod species will first be presented to provide a better understanding of the role of saliva in host defence, including haemostasis and the immune response.

\section{Blood-feeding behaviour among haematophagous arthropods}

The phylum Arthropoda represents the vast majority of metazoan life forms on earth, with a species richness estimated at 5-10 million [52]. The blood-feeding habit has arisen and evolved independently in more than 14,000 species from 400 genera and five orders in the arthropod taxonomy $[1,53]$. These independent adoptions of haematophagy during the evolution of arthropod vectors required morphological, behavioural and biochemical adaptations in order to remove blood from the skin of vertebrate hosts. Indeed, blood is not an easy access nutrient due to its cryptic nature in addition to the host's behavioural and biological defensive response.

Mouthparts have adapted the following two strategies to obtain blood from vertebrates: (i) lacerating dermal capillaries and collecting the nutritive fluid in a hemorrhagic pool (pool feeding or telmophagy, e.g., flies from the families Tabanidae and Psychodidae and Ixodoidae (ticks) and (ii) by directly inserting mouthparts into a capillary (capillary feeding or solenophagy, e.g., Culicidae 
(mosquitoes) and Reduviidae (bugs). The development of these blood-feeding habits may have occurred in several different ways. A prolonged and close association between terrestrial hosts and arthropods that regularly fed on dead parts of the host's body or organic debris associated with the nests or burrows may have gradually established more profound parasitic relations characterised by switching to a haematophagous diet. Alternatively, the development of haematophagy would have been facilitated in some capillary feeders by morphological preadaptation of their ancestors to phytophagy or entomophagy [2,54-56].

Other important blood-feeding behaviours are displayed among haematophagous arthropods, including the duration of blood-feeding (which can range from few minutes for Culicidae [57] to several days for ticks [58]), the rate of anthropophily [59] or the obligate versus facultative haematophagous diet [56]. These singularities among different haematophagous arthropods, adding to other behavioural or biological features, such as the length of the extrinsic incubation period (time between the acquisition of an infectious agent by a vector and its ability to transmit it to other vertebrate hosts) [60], the nycthemeral activity [61] or the reproductive strategies ( $\mathrm{K}$ - and $\mathrm{r}$ - selected arthropods) [62], are additional features that may have significant implications on disease transmission and on the implementation of anti-vectorial strategies. However, whichever blood-feeding strategies or feeding behaviour is used, each adoption of haematophagy requires solutions to counteract vertebrate host haemostatic, inflammatory and immune responses. At the molecular level, haematophagous arthropods have also developed, by an evolutionary process, an important diversity of pharmacological compounds in their saliva in order to prevent these physiological responses.

\section{The role of saliva in blood-feeding}

\section{Salivary components and host's haemostasis}

Haemostasis is a host cellular and molecular response that prevents blood loss from a damaged vessel through several redundant processes, such as blood vessel vasoconstriction, formation of a primary platelet plug (primary haemostasis) or vessel strengthening by blood coagulation (secondary haemostasis) [For review: $[63,64]]$.

Damage to blood vessel endothelium first results in vasoconstriction that decreases blood flow at the bite site to limit the haemorrhage. Two strategies are employed by haematophagous arthropods to prevent this phenomenon. Some arthropods display salivary components which block host vasoconstrictor agents, such as peroxidase from the Anopheles albimanus mosquitoes [65]. Other arthropods have strong vasodilators in their saliva. For example, Lutzomyia longipalpis sand flies and Simulium vittatum black flies express maxadilan and Simulium vittatum erythema protein (SVEP) in their saliva, respectively, which are the most potent known vasodilators $[66,67]$. These two species are pool feeders that require strong vasodilatory substances to increase blood flow perfusion in superficial regions of the skin. Closely related species can use separate mechanisms to counteract vascular compression as illustrated by Phlebotomus sand flies that express adenosine and 5'AMP vasodilators instead of maxadilan in their saliva [68].

Vascular injuries due to the penetration of arthropod mouthparts in the host skin are also accompanied by the activation of platelets, which aggregate within seconds to form a haemostatic plug using fibrinogen as a connecting agent $[63,69]$. Convergent paths of evolution have lead to similar molecules in different arthropod species that inhibit or scavenge a panel of platelet-aggregating factors (Additional file 1 Figure 1). Among them, apyrase, an enzyme that hydrolyses ADP released by damaged cells and activated platelets, is ubiquitously found in the saliva of various haematophagous arthropods [70-79]. Distinct salivary proteins from a single species could present redundant effects, as illustrated by the Rhodnius prolixus bug saliva, which contains both a salivary apyrase and a protein named Rhodnius prolixus aggregation inhibitor 1 (RPAI-1) that inhibits platelet aggregation by direct binding to ADP [71,80]. More diversified molecules targeting other platelet aggregation agonists (e.g., thrombin, serotonin (5-HT) or thromboxane $\mathrm{A}_{2}$ ) are exhibited by other arthropods (Additional file 1 Figure 1).

This platelet activation prepares the implementation of secondary haemostasis by exposing the surface of activated platelets to coagulation proteins. Through a series of reactions involving several blood coagulation factors, the coagulation pathway (including the contact activation pathway and tissue factor pathway) is propagated until the formation of thrombin. The latter converts circulating soluble fibrinogen into insoluble fibrin, leading to blood clotting and complete cessation of haemorrhage [81-83]. As a result of convergent evolution, a variety of unrelated arthropod species have developed salivary inhibitors toward thrombin, a prime target to overcome both primary and secondary haemostasis (Additional file 1 Figure 1). As observed for primary haemostasis, more than one anticoagulant compound can be found in the saliva of a single haematophagous arthropod, as exemplified by hamadarin and anophensin, which are two anticoagulants targeting the contact activation pathway isolated in An.stephensi [84,85]. This redundancy of function reinforces the efficiency of the anti-haemostatic response. 


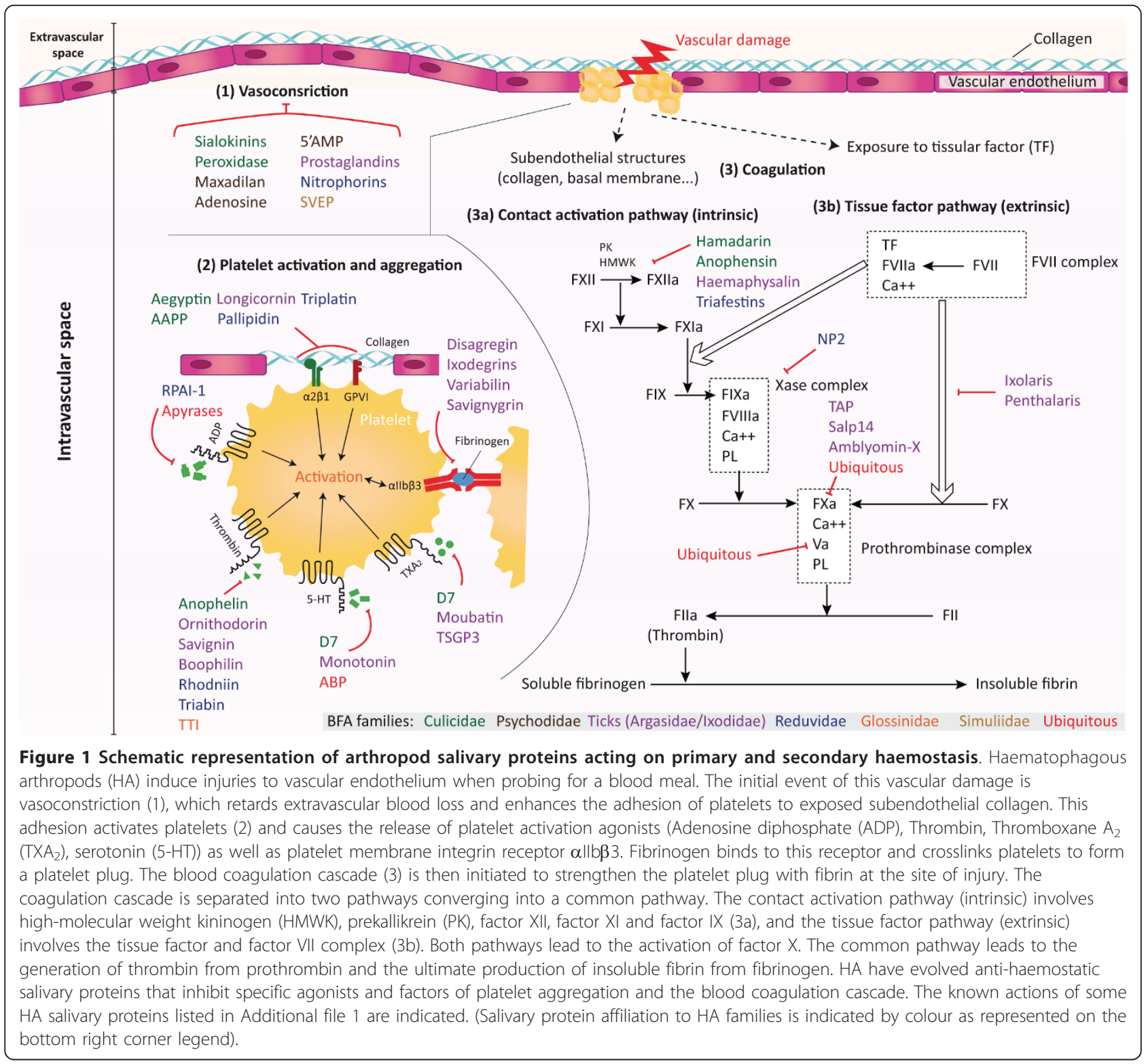

\section{Salivary components and host's immunity}

Adding to haemostatic defences, vertebrate hosts have evolved systems of immune defences to eliminate foreign organisms in the body, which can largely impair haematophagous arthropod blood-feeding. Tissue injury causes the immediate onset of acute inflammation and innate immunity, which promote tissue repair, prevent colonisation of the damaged tissues by opportunistic pathogens and initiates adaptive immunity, which is more specific.

Inflammation is characterised by multiple interactions between resident cells of the epidermis and dermis, such as endothelial cells, leucocytes, mast cells, neutrophils and platelets, which are the first to make contact with arthropod mouthparts as well as their saliva and their potential pathogens. These cells release pro-inflammatory mediators and chemotactic factors such as histamine, macrophage inflammatory protein- $1 \alpha$ (MIP-1 $\alpha)$ and leukotrienes [86-88], which activate and recruit leucocytes at the site of haemorrhage. The majority of salivary molecules inhibiting or scavenging these proinflammatory agonists were extensively studied in tick saliva (e.g., argasid or ixodid) compared to other arthropods (Additional file 1 Figure 2). Due to their habit of remaining attached to their host for a long period to feed until repletion, ticks are strongly dependent upon the potent immunosuppressive activities of their salivary components. Tick salivary components can then act on different actors of the innate immune response, such as the complement system [89-91], macrophages [92], 


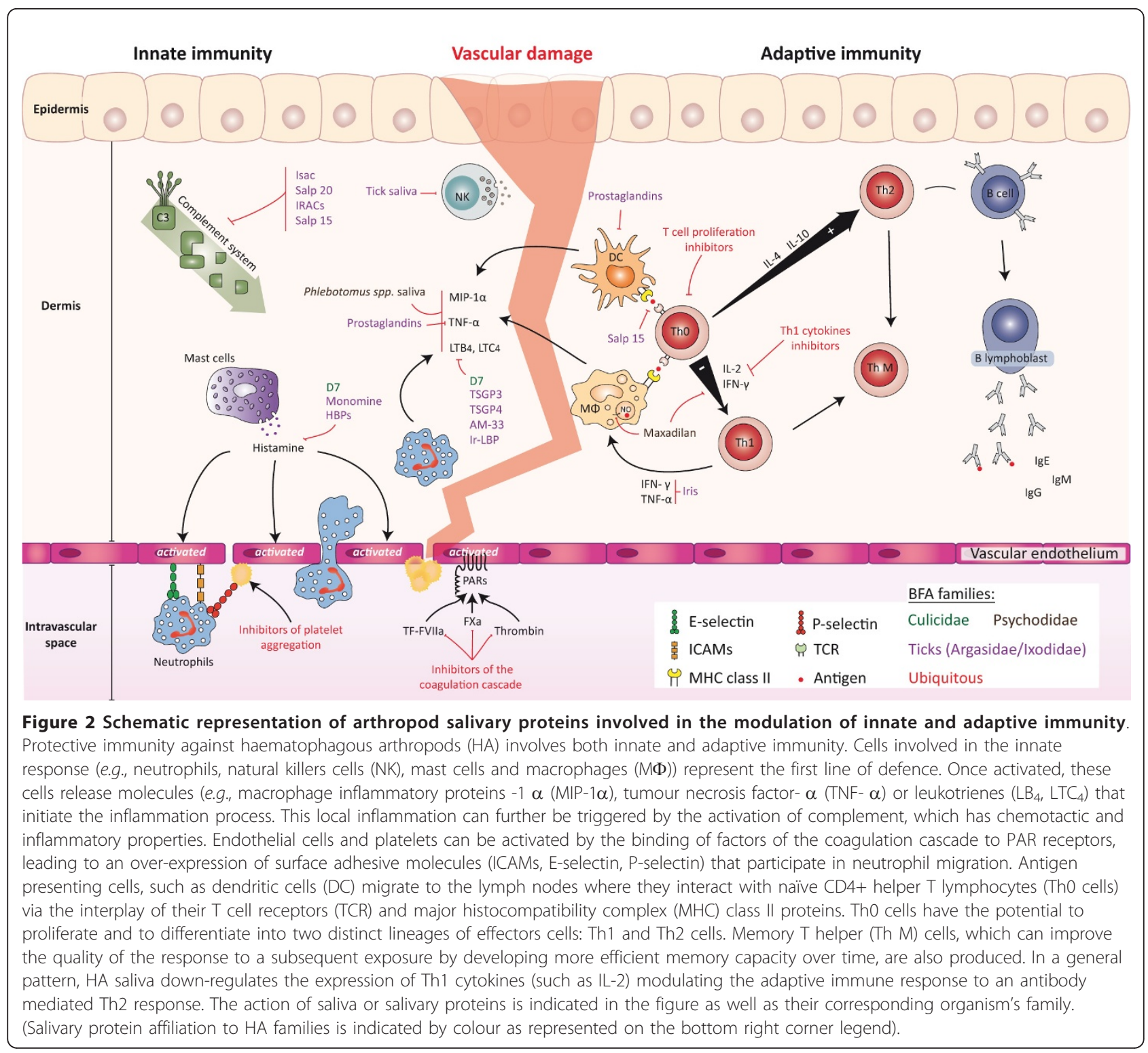

natural killer cells $[93,94]$ and the synthesis of proinflammatory cytokines $[95,96]$, to succeed their blood meal. The suppressive effect induced by saliva on innate immunity was less studied in other haematophagous arthropods. Even though whole saliva or salivary gland extracts from Culicidae and Psychodidae have been found to induce a suppressive effect on innate immunity $[97,98]$, several immunosuppressor components remain to be determined at the molecular level.

Tissue damage and inflammation can lead to the extracellular production of adenosine from ATP degradation. Adenosine can have analgesic or pronociceptive effects depending on the activation of different peripheral receptors [99]. Pain perception can induce defensive behaviours from the host that could be deleterious to haematophagous arthropods. As a consequence, adenosine deaminase enzymes detected in saliva of various arthropods [100-102] were proposed to suppress pain perception by degrading adenosine at the bite site [101].

The innate immune system can also influence the type of adaptive immune response that develops. Haematophagous arthropod saliva can greatly impair the development of an appropriate adaptive immune response by the host by altering the function of antigen presenting cells (APC), such as macrophages [103] or dendritic cells (DC) $[95,104,105]$. These cells are involved in the capture and processing of salivary or pathogen antigens at the bite site, as well as in antigen presentation to $\mathrm{T}$ lymphocytes in the draining lymph nodes [106], which promotes cell and antibody mediated responses 
$[107,108]$. As a generalized pattern, salivary gland extracts from several haematophagous arthropods can inhibit Th1 cytokines secretion, such as IFN- $\gamma$ and IL-2 [109-112], promoting the development of an antibodymediated Th2 response [113-117]. This polarisation of host immunity toward a Th2 response (to the detriment of a Th1 cell-mediated response) is beneficial to the success of the blood feeding but it may also have a beneficial impact on pathogen transmission.

\section{Salivary components and enhancement of vector-borne pathogens infection}

The discovery of the immuno-modulatory property of saliva has stimulated several research groups to study the involvement of salivary proteins from diverse vectors in the transmission and the establishment of corresponding pathogens into their hosts.

Titus and Ribeiro were the first to describe the enhancing effect of sand fly salivary gland extracts on cutaneous leishmaniasis when coinoculated with Leishmania promastigotes. Mice injected with Leishmania parasites concomitantly with a small amount of salivary gland proteins developed larger lesions and harboured more parasites than controls [118]. The enhancing effect of salivary extracts was confirmed with other Leishmania and sand fly species $[119,120]$. Subsequent studies have demonstrated that the injection of Triatominae bug saliva into the skin of mice in the presence of Trypanosoma cruzi parasites induced an up to six-fold blood parasitaemia [121], and that the saliva of ixodid ticks potentiated the transmission of Thogoto virus [122]. Interestingly, enhancement of Thogoto virus infection was only observed with salivary gland extracts derived from metastriate ixodid ticks but not from prostriate ixodid ticks, argasid ticks or mosquito saliva [122]. These results highlight the strong specificity of the vector/pathogen interaction that is needed in order to potentiate this enhancing transmission effect and suggest that this effect may involve a limited number of specific proteins to the haematophagous arthropod species or genus.

Effectively, in Lutzomyia longipalpis sand fly, the vasodilator maxadilan appears as the principal salivary molecule responsible for this enhanced parasite transmission as it exacerbates infection with Leishmania major to the same degree as whole saliva [123]. For Borrelia burgdorferi, the spirochetal agent of Lyme disease, the Salp15 protein expressed in Ixodes scapularis tick saliva enhances its transmission and survival within the vertebrate host. The spirochaete pathogen specifically up-regulates the expression of Salp15 and associates with it in order to be protected from borreliacidal effects induced by antibody-mediated killing [124]. The enhanced infection induced by saliva seems to be a widespread phenomenon in various vector species and for various viruses, bacterial or parasite pathogens [121,122,125,126]. Mosquito saliva might also accelerate and amplify infections of West Nile virus [127,128], La Crosse virus [129] or Cache-valley virus [130]. All these data suggest that haematophagous arthropod vectors are not simply "flying or crawling" syringes but rather play a dynamic role in the host/vector/pathogen relationship. The participation of saliva components in this transmission is supported by the increase infectivity observed when pathogens are delivered to the host by haematophagous arthropod bites compared to delivery by a syringe without saliva proteins [129,131-133].

All salivary proteins characterized in various hematophagous arthropods so far give a global overview of their complexity as well as their diversity both at their molecular level as well as their targets. It is interesting to note that only a minority of these salivary proteins has been assigned a precise function. For instance, concerning any tick species with a known genome or salivary gland transcriptome, less than $5 \%$ of the salivary proteins have their function verified [5]. Further knowledge on the pharmacology of arthropod salivary proteins might thus lead to the discovery of novel vasodilator, anti-platelet, anti-clotting, analgesic or immunomodulatory compounds, used by hematophagous arthropods to counteract host defenses. In addition, these salivary molecules might also provide new immunological tools to combat the direct and indirect nuisance caused by these hematophagous arthopods.

\section{Salivary proteins and host antibody response: immunological tools in sight?}

Saliva of haematophagous arthropods and allergy

Since the mid-1930s, numerous studies have described host immediate-type hypersensitivity (ITH) reactions in response to the bite of various haematophagous arthropod families, such as Psychodidae [134], Culicidae [135-137] or Glossinidae [138]. This ITH skin reaction, also known as type I hypersensitivity, is now widely accepted to be an allergic reaction which involves the production of IgE antibodies in response to specific salivary allergens [6]. Several studies have attempted to characterise the allergens involved in ITH by using different techniques (e.g., skin testing, RAST, ELISA, Immunoblot) and different allergen preparations with the aim of developing tools for diagnosis and treatment of allergic reactions $[139,140]$. The comparison of the allergenic potency of whole body, thoracic and abdominal hemolymph and salivary glands from Triatoma protracta (reduviid bug) by RAST inhibition demonstrated that the allergens were concentrated in the salivary glands [139]. Similar results were observed for the Ixodes holocyclus tick [141]. Recently, Wongkamchai 
and colleagues have gained further evidence that major allergens are more abundant in saliva, followed by salivary gland extracts and whole body extracts from four mosquito species [142]. These different studies confirmed that the more concentrated source of allergens is located in saliva and salivary glands from haematophagous arthropods. Thus, saliva appears to be the prime antigenic source for testing or treating haematophagous arthropod-induced allergic reactions [143].

However, the collection of saliva is tedious, time consuming and constitutes a major drawback to the widespread medicinal use of these salivary components [143]. Hence, the synthetic production of arthropod vector saliva allergens is a promising alternative strategy for producing safe and highly standardized allergens on a large scale. A panel of studies using the immunoblot method have revealed a number of salivary proteins detected by IgE antibodies of individuals with skin hypersensitivity to arthropod bites, including mosquitoes [140,144-148], ticks [141,149] or reduviid bugs $[139,150]$. Some of these salivary allergens are now well characterised. For example, three recombinant Aedes aegypti salivary allergens corresponding to a $68 \mathrm{kDa}$ salivary apyrase (rAed a1), a 37-kDa protein belonging to the D7 family (rAed a2) and a $30 \mathrm{kDa}$ salivary gland allergen (rAed a3) elicit predominantly IgE responses in mosquito-allergic individuals [151,152]. The authors concluded that these recombinant allergens could greatly facilitate the diagnosis and immunotherapy of mosquito allergies. Recombinant salivary allergens were also evaluated in other haematophagous arthropod species and are presented in Table 2.

Currently, whole body extracts from mosquitoes are used in the diagnosis and immunotherapy of mosquito bite allergies [153,154]. However, these commercially available samples contain many extraneous proteins that are not present in mosquito saliva and might interfere with diagnostics or may even cause additional sensitisation in subjects with a history of allergic reactions to mosquito bites. Moreover, the treatment of mosquito allergies is not widely used because considerable variations in the biological activity of these mosquito whole body allergen extracts have been described [155]. Thus, synthetic allergens appear to be a promising alternative for the diagnosis of allergic individuals, but also may improve desensitisation protocols and overcome the lack of standardisations in allergen immunotherapy $[7,142]$.

\section{Saliva of haematophagous arthropods and vaccines}

Over the course of the past 20 years, it has been observed that a history of exposure to uninfected bites has the ability to protect against several vector-borne infections, including tularaemia [156] and Lyme borreliosis [157] in animals pre-exposed to tick bites. The hypothesis that salivary components could be effective vaccine candidates for reducing the morbidity of vectorborne diseases in exposed individuals was strengthened by the discovery that pre-exposure of mice to salivary

Table 2 Recombinant salivary proteins characterized in hematophagous arthropods and their immunological applications

\begin{tabular}{|c|c|c|c|c|c|}
\hline $\begin{array}{l}\text { Protein } \\
\text { names }\end{array}$ & Organisms & Additional informations & $\begin{array}{c}\mathrm{MW} \\
{[\mathrm{kDa}]}\end{array}$ & Application & Ref. \\
\hline rAed a1 & Aedes aegypti & Salivary apyrase & 68 & Allergy & {$[151,152]$} \\
\hline rAed a2 & Aedes aegypti & Belong to the D7 family & 37 & Allergy & {$[151,152]$} \\
\hline rAed a3 & Aedes aegypti & 30 kDa salivary gland allergen & 30 & Allergy & {$[151,152]$} \\
\hline Procalin & Triatoma protracta & Belong to the lipocalin family & 20 & Allergy & {$[225]$} \\
\hline Arg r 1 & Argas reflexus & Belong to the lipocalin family & 17 & Allergy & {$[227]$} \\
\hline Der-p2 & Ixodes ricinus & $\begin{array}{c}\text { Dermatophagoides pteronyssinus allergen- } \\
\text { like }\end{array}$ & 15.6 & Allergy & {$[226]$} \\
\hline TAg5 & Glosina m. morsitans & Tsetse Antigen 5 & 28.9 & Allergy & {$[228]$} \\
\hline Maxadilan & Lutzomyia longipalpis & - & 9.5 & Vaccine candidate & {$[123]$} \\
\hline SP15 & Phlebotomus papatasi & - & 15 & Vaccine candidate & {$[162]$} \\
\hline rLJM19 & Lutzomyia longipalpis & - & 11 & Vaccine candidate & {$[229]$} \\
\hline Salp15 & Ixodes scapularis & - & 14.7 & Vaccine candidate & [163] \\
\hline gSG6 & Anopheles gambiae & - & 10 & $\begin{array}{l}\text { Immunological marker of } \\
\text { exposure }\end{array}$ & {$[218,219,230,220]$} \\
\hline rTC & $\begin{array}{l}\text { Amblyomma. } \\
\text { americanum }\end{array}$ & Calreticulin & 47.5 & $\begin{array}{l}\text { Immunological marker of } \\
\text { exposure }\end{array}$ & {$[221]$} \\
\hline rLJM11 & Lutzomyia longipalpis & Yellow-related protein & 43 & $\begin{array}{l}\text { Immunological marker of } \\
\text { exposure }\end{array}$ & {$[223,224]$} \\
\hline rLJM17 & Lutzomyia longipalpis & Yellow-related protein & 45 & $\begin{array}{l}\text { Immunological marker of } \\
\text { exposure }\end{array}$ & {$[223,224]$} \\
\hline
\end{tabular}


gland extracts of Phlebotomus papatasii abrogates the size of dermal lesions and reduces Leishmania major parasite loads in tissue [158]. More recently, it was shown that pre-exposing mice to Anopheles stephensi bites could protect them from rodent malaria [159], but these results are controversial [160].

These protective effects might be partly due to the development of host immunity against vector salivary proteins described as enhancing pathogen establishment. Based on these reflections, Morris and colleagues have tested the potential of Lutzomia longipalpis maxadilan as a vaccine candidate to protect mice against Leishmania infection (Table 2) [123]. Mice vaccinated with synthetic maxadilan were highly resistant to infection, as evidenced by smaller cutaneous lesions and a shorter healing period compared to controls. As maxadilan is only expressed in New World Psychodidae from the genus Lutzomia [68], it cannot confer protection against Leishmania infection transmitted by Old World sand flies from the genus Phlebotomus. However, vaccination with SP15, a $15 \mathrm{kD}$ salivary protein from the Old World $P$. papatasi sand fly, protected mice from Leishmania infection $[161,162]$. These results highlight the challenge in developing a universal vaccine to control a specific pathogen transmitted by several vector species. Indeed, the variability in the salivary repertoire of closely related vector species implies that one must develop a salivary vaccine candidate for each different vector transmitting a specific pathogen. Additionally, one must take into account the geographical distribution of these vectors to determine the appropriate candidates that should be used during vaccination campains.

The efficacy of the Salp15 salivary protein as a vaccine candidate, the other well described salivary molecule isolated in I. scapularis ticks with an enhancing effect on pathogen transmission, was also tested in vivo. Mice immunised with recombinant Salp15 proteins were partially protected against Lyme borreliosis spirochetes transmitted by I. scapularis ticks [163]. Interestingly, the co-immunisation with Salp15 and OspA (a Borrelia burgdorferi outer-surface protein [164]) exerts a better protection against $B$. burgdorferi than either of these two candidates when used alone. Thus, the conjunction of salivary proteins to traditional pathogen-based vaccine could improve host protection against vector-borne disease infection. To our knowledge, no vaccine candidates have been developed against salivary components from other haematophagous arthropods. This relatively new vaccine approach (i.e., targeting arthropod salivary components required by a pathogen for its establishment in the host) necessitates the characterisation of salivary components exhibiting an enhancing effect on pathogen infection. The development of multi-epitope vaccines by the combination of pathogen-derived antigens with appropriate salivary antigens from their corresponding vectors could provide a better protection against vector-borne diseases than pathogen-derived vaccine candidates alone. Recently, An. stephensi saliva was reported to enhance the progression of cerebral malaria in a murine model [165]. The further characterisation of salivary components involved in this effect might lead to potential vaccine candidates, which could be used in combination with other malaria vaccine candidates to protect against severe malaria [166,167].

Other vaccine strategies using salivary proteins were undertaken in order to reduce host/vector contact by avoiding blood intake or diminishing the duration of the blood meal, particularly in ticks [168-170]. Additionally, vaccine candidates targeting gut or body haematophagous arthropod antigens were also developed to either disrupt the biology of the vectors or to block pathogen transmission. These approaches are promising to control vector-borne diseases but are beyond the scope of this review; supplementary details can be found in other works [171-175].

\section{Saliva of haematophagous arthropods and exposure markers \\ Relationship between anti-saliva IgG responses and haematophagous arthropod exposure}

The absence of an antibody response against saliva from mosquitoes or Culicoides midges in the sera of children [176] or horses [177] living in Iceland (a country exempt from these two biting arthropods) and the appearance of an IgG antibody responses in animals or humans following exposure to haematophagous arthropod bites [144,177-179] are strong arguments suggesting that the acquisition of an antibody response against haematophagous arthropod saliva is exposure dependent.

The correlation between arthropod exposure and the level of anti-saliva IgG antibody was first evidenced using the sera from outdoor workers (in New Jersey, U. S.A.) who had been exposed to Ixodes damini ticks during their forestry activities [180]. Moreover, a significant decrease of the IgG anti-tick saliva levels was observed in the absence of tick exposure for several months (from October to January) [180]. From this point, several serological analyses demonstrated a relation between the density of diverse haematophagous arthropods and the level of antibody responses against their saliva. A kinetic analysis of the serological response against Aedes communis saliva from individuals living in Finnish Lapland indicated that seasonal exposure to mosquito bites elicited more intense antibody responses toward salivary antigens [181]. In a larger cohort, using sera from 1,059 Canadian blood donors sampled before and after the summer mosquito exposure peak, Peng and colleagues showed significant higher level of IgG 
antibody against Aedes vexans saliva after the summer peak exposure [182]. Higher levels of anti-saliva IgG antibodies were also detected in individuals exposed to Glossina bites compared to non-exposed individuals [50]. These works demonstrated that levels of serological immune responses could be influenced by seasonal variations of the level of haematophagous arthropod densities.

Additionally, Orlandi-Pradines and colleagues have evaluated the consequences of a transient exposure to An. gambiae and Ae. aegypti mosquitoes in French travellers during a five-month journey to tropical Africa on anti-saliva IgG responses [49]. This study reported that several travellers from areas free of An. gambiae and Ae. aegypti mosquitoes developed an antibody response against saliva from these two unrelated mosquitoes. Thus, transient exposure (e.g., seasons or travel into endemic areas) to haematophagous arthropod bites seems sufficient for developing an IgG response against arthropod saliva. Additionally, IgM antibodies directed against Triatoma infestans saliva can be detectable as early as one day after a single encounter with several triatomine bugs and decrease even more rapidly (18 days) than IgG in chickens [183]. These IgM responses seem highly sensitive to the detection of bug exposures; however, no association was observed between level of exposure and IgM antibody levels. These results highlight the potential use of the short persistence of IgM responses (as a complement to measuring IgG responses) as an indicator of recent exposure to haematophagous arthropods. The observed link between antisaliva antibody responses and haematophagous arthropod exposure, as well as the waning of these antibody responses after a period of non-exposure, favour the potential use of immunogenic saliva as an immunological marker of exposure. Indeed, simple blood sampling would give an indication of individual exposure to the bites of specific vectors and could be used to complete entomological surveys or to replace them when human landing catch or other trapping methods are difficult to implement [184]. Saliva-based immunological markers of exposures would also be more appropriate than measuring vector-borne disease incidence in clinical trials to assess the effectiveness of anti-vectorial devices in areas with low pathogen transmission intensity [185]. Finally, it could be an alternative strategy compared to entomological methods (i.e., human landing catch) to assess vector bite exposure particularly in children [186].

In a recent clinical assay, Drame and colleagues confirmed the validity of using An. gambiae crude saliva as an immunological marker to assess the efficaccy of insecticide-treated nets (ITNs) in a malaria hypo-endemic transmission area [187]. They measured anti-saliva IgG levels, blood parasitaemia and vector densities before and after the introduction of ITNs. A significant decrease in the anti-saliva IgG response was observed after the introduction of ITNs. This diminution of antibody response was associated with a drop in parasite load but not with vector densities as measured by light traps, a standard but highly biased and imprecise entomological methods. Recently, antibody responses from sentinel guinea pigs to salivary proteins of T. infestans, the vector of T. cruzi, was shown to be a powerful tool for the evaluation of vector control interventions against Chagas disease [188]. These studies demonstrated that anti-saliva antibody responses could be efficient tools to assess the effectiveness of antivectorial strategies implemented to control diverse vector borne diseases by giving an estimation of the real intensity of haematophagous arthropod bites at the individual level. Thus, variations of the IgG antibody level appeared to be correlated with haematophagous arthropod density, which was dependent on several factors, such as seasons, ecological environments, individual activities or the level of anti-vectorial protection.

\section{Diversity and specificity of salivary components}

As some areas can exhibit a high biodiversity in terms of haematophagous arthropod species [189,190], a high level of specificity is necessary to assess individual exposure by immunological tests based on haematophagous arthropod saliva. Several studies have reported diverse degrees of cross-reactivity between different vector species, ranging from low $[191,192]$ to high species-specificity [150,193-195]. The presence of cross-reactivity was often described in related species [191,192], suggesting that this phenomenon can occur in closely related saliva components.

The specificity of the saliva based immunological test is a prerequisite to assess individual exposure to a specific genus or species of arthropods. An important step forward in the knowledge of the salivary protein diversity in the phylum Arthropoda was the cataloguing of salivary gland proteins expressed and secreted in several species of haematophagous arthropods. The recent elucidation of the genome of major haematophagous arthropods [196-200] added to increasing transcriptomic and proteomic work on salivary glands, making it possible to identify salivary molecules in various haematophagous arthropods. To date, the transcription repertoire (named sialotranscriptome) of at least 30 different species of haematophagous arthropods has been drawn up, revealing a number of both ubiquitous and specific proteins throughout the taxonomic hierarchy [201-208]. The independent evolution of haematophagous arthropods and host immune pressure over the salivary products led to a diversity of pharmacological molecules even among different genera within a same family $[205,209]$. An insight into the taxonomic variability at 
the protein sequence level of some haematophagous arthropod salivary proteins is shown on Figure 3. The homology/diversity of salivary proteins can be observed at two levels: (i) Homologous salivary proteins can be conserved at different taxonomic levels from genus to the entire arthropod phylum and (ii) the distribution of percentage identity of homologous proteins inside each taxonomic level is highly variable. This supports the existence of numerous candidates that can be used to assess individual exposure to specific haematophagous arthropods.

Interestingly, studies on haematophagous arthropod saliva generally use inbred laboratory strains. However, for one species, there exist distinct colonies coming from arthropods collected in the field that differed in their origins and laboratory colonisation histories. In order to evaluate sialome divergence, which could occur following the rearing of haematophagous arthropods over several decades (e.g., mosquitoes), under laboratory conditions, the sialomes (i.e., saliva and salivary gland) of three mosquito colonies (i.e., Ae. aegypti colonies Rockefeller, PAEA and Formosus) were compared using 1D SDS-PAGE $[143,210]$. At the saliva and salivary gland level, no major differences were detected between these three colonies, suggesting that the expression of salivary proteins is highly conserved across populations.

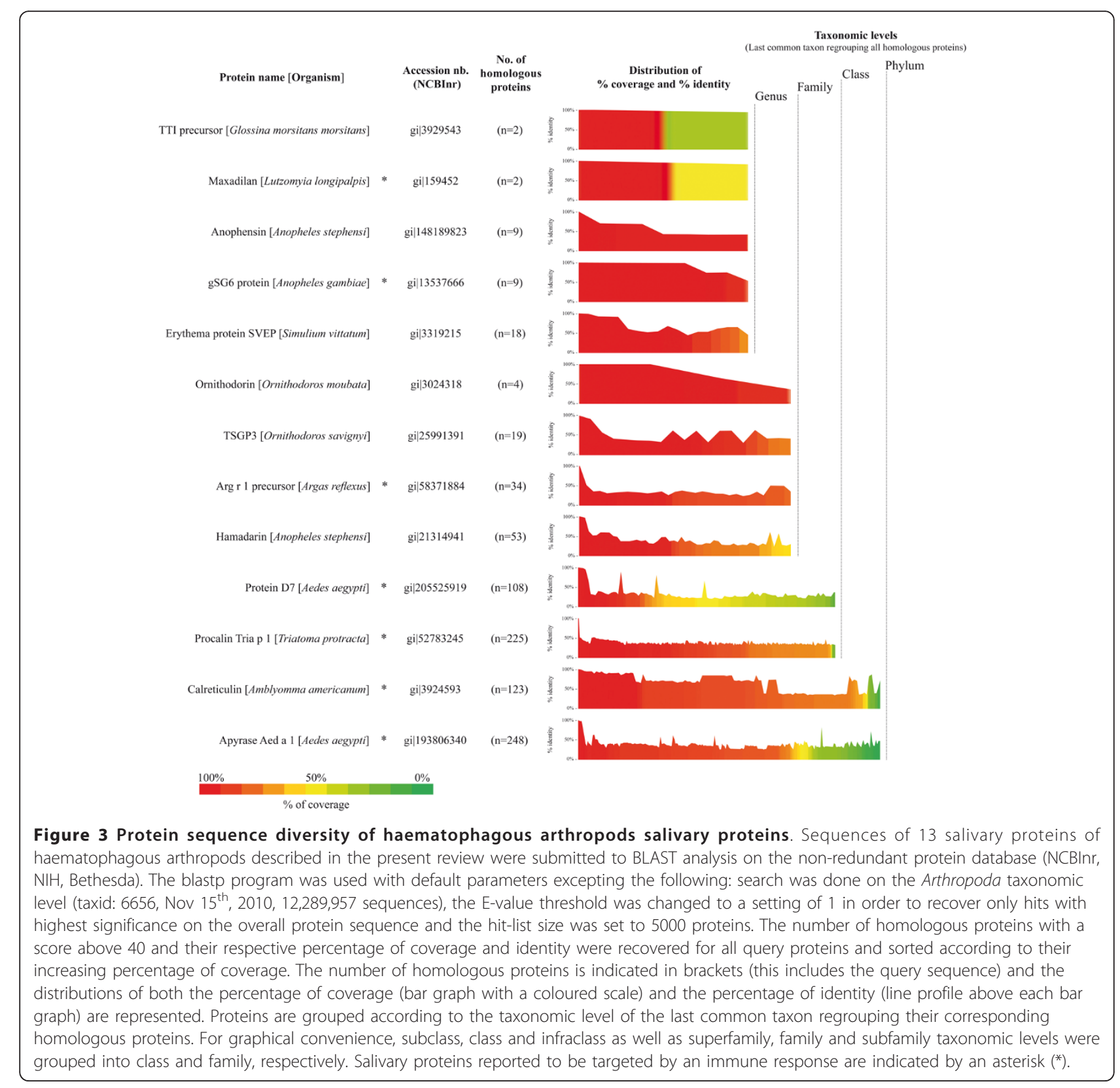


But these data could not exclude the possibility that a long history of laboratory rearing might have induced a homogenisation of salivary protein repertoires, which may differ from their field counterparts. This loss of salivary protein diversity as a result of long-term colonization was hypothetised to be responsible of the observed positive effects on the outcome of Leishmania infection on mice pre-immunized with sand fly saliva [211]. Indeed, pre-immunization of mice with saliva from long-term colonized phlebotomine sand flies, was reported to induce a better protection against Leishmania infection than saliva from wild-caught or recently colonised sand flies [211,212]. This preserved repertoire of salivary proteins at the species level is essential to develop anti-saliva based immunological tools to assess individual exposure to different haematophagous arthropod colonies settled in various areas throughout the world. The access of salivary samples from wild-caught arthropods using convenient procedures adapted to field works would allow to assess the sialome diversity between laboratory reared and wild arthropods [213].

Synthetic salivary components as immunological markers of exposure

Major limits for developing a biological test of exposure to haematophagous arthropod bites are the difficulty of collecting saliva or salivary gland extracts and the lack of standardisation in sampling. Effectively, the salivary protein content of haematophagous arthropods can vary according to their sex, age or diets [214-216]. Thus, a gain of sensitivity, specificity and reproducibility could be obtained by identifying the genus or species-specific immunogenic salivary proteins and to produce them in recombinant form or synthetic peptides.

The recombinant Anopheles gambiae salivary gland protein 6 (gSG6), a small salivary protein highly preserved in the Anopheles genus [217], was evaluated as an immunological marker of exposure [218]. The recombinant protein was detected by IgG antibodies from children exposed to the bite of $A n$. gambiae. BLAST analysis (NCBInr, NIH, Bethesda, Nov 15th, 2010) revealed that homologous proteins of gSG6 protein can only be found in 8 Anopheles species so far, suggesting its specificity to the Anopheles genus (Figure 3). This protein has recently been proposed as a serological candidate marker of exposure to Afrotropical malaria vectors [219,220]. Human hosts exposed to Amblyomma americanum and Dermacentor variabilis ticks also develop a specific IgG response against a recombinant calreticulin (rTC) protein isolated from the salivary glands of the $A$. americanum tick [221]. The use of recombinant salivary proteins, which are highly preserved between several related vector species, could be useful in assessing the risk of disease transmission in individuals living in areas where vector diversities are not well characterised at the species level. Interestingly, anti-rTC antibody seropositivity has higher specificity but lower sensitivity than antibodies directed against whole saliva in detecting individuals that have been exposed to ticks [222]. The use of a single recombinant salivary protein to assess individual exposure to tick bites may explain this lack of sensitivity. Indeed, the use of two recombinant proteins (named LJM17 and LJM11) was reported to be more effective and sensitive than whole saliva to estimate the level of exposure to Lutzomia longipalpis sand flies, vectors of Leishmania parasites [223,224].

Recombinant proteins that have been primarily produced for their biological properties or their role in allergic responses (Table 2) could also be considered potential markers of exposure candidates [225-229]. Some of these proteins appear to be relatively specific to the vector family or genus (Figure 3 ) and might be promising epidemiological markers of vector exposure. Ribeiro and colleagues classified conserved salivary proteins at different taxonomic levels in the suborder Nematocera from which some other specific antigenic candidates might emerge [205].

The detection and selection of highly specific peptides inside the whole salivary protein sequence could further increase the specificity of such immunological markers and reduce production costs. In order to optimise the specificity of the gSG6 biomarker, Poinsignon and colleagues have designed a gSG6-based peptide sequence (gSG6-P1) according to its predicted immunogenic properties [218]. A positive association between the anti-gSG6-P1 IgG responses and the level of exposure was observed in individuals exposed to An. gambiae bites. This peptide was also detected in individuals exposed to a very low number of the malaria vector bites, suggesting its potential to reveal An. gambiae exposure in a context where classical entomological methods would be employed with difficulty (i.e., urban areas, altitude, travellers) [230].

Taken together, all these data support the use of immunogenic salivary components as new tools for identifying individuals at risk to vector-borne diseases and for monitoring haematophagous arthropod populations and anti-vector intervention strategies. A gain of sensitivity and specificity could be achieved by the selection and production of recombinant antigens or peptides that do not share sequence homology with other haematophagous arthropod species. Such synthetic products increase the amount of available protein for large cohort studies using high-throughput methods such as Luminex technology. These multiplex assays are cost and time effective and have proven to be useful strategies for the detection of serum antibodies directed against 
infectious pathogens [231,232] and for evaluating individual exposure to vector borne diseases [233].

\section{Conclusion}

In order to facilitate their blood meals, haematophagous arthropods have elaborated a wide range of salivary components that have essential roles in counteracting host haemostatic defences. In addition to these pharmacological activities, salivary components can modulate host immunity at the bite site and induce an immune environment favourable for pathogen transmission. This immuno-modulation is associated with the production of specific antibody responses. Since the 1980s, several studies have investigated the antibody responses of vertebrate hosts against salivary proteins in an initial attempt to treat uncomfortable allergic reactions to haematophagous arthropod bites. The immunogenic properties of some salivary proteins can be used as vaccine candidates for improving host protection against some vector-borne diseases. Salivary proteins are likely to become immunological markers for relevant estimation of vector/host contacts, of the effectiveness of various control or surveillance programs, and an estimation of the pathogen transmission risk to complement methods that are currently available. A gain in sensitivity, specificity and reproducibility is expected to be obtained by the identification of species-specific immunogenic salivary peptides or the combination of several recombinant salivary proteins.

\section{Additional material}

Additional file 1: Anti-hemostatic and immunomodulatory salivary proteins in hematophagous arthropods. Known anti-hemostatic and immunomodulatory properties of salivary proteins from diverse hematophagous arthropods are presented.

\section{Acknowledgments and Funding}

This study was supported by the French Armed Forces Medical Service and the Délégation Générale pour l'Armement (DGA, SALIVAPULS project, Grant 07ca406 and ARTHROSER project, Grant 10ca401). The post-doctoral fellowship of ID and NW was supported by the Foundation Infectiopole Sud. We thank Jean-Michel Berenger for his thoughtful comments and inputs.

\section{Author details}

'Unité de Parasitologie - UMR6236 - IFR48, Antenne Marseille de l'Institut de Recherche Biomédicale des Armées (IRBA), Le Pharo, BP 60109, 13262 Marseille Cedex 07, France. ²Laboratoire de Génétique et Evolution des Maladies infectieuses, UMR 2724 CNRS/IRD, Montpellier, France. ${ }^{3}$ Unité d'Entomologie Médicale, Antenne Marseille de l'Institut de Recherche Biomédicale des Armées (IRBA), Le Pharo, BP 60109, 13262 Marseille Cedex 07, France. ${ }^{4}$ Institut Pasteur de Madagascar, B.P. 1274, Ambohitrakely, 101 Antananarivo, Madagascar.

\section{Authors' contributions}

FA and AL conceived the intellectual content of the article. FA and AL collected results presented here and wrote first draft of the manuscript. FA designed all figures. FA, ID, NB NB, DM, FP, TF, CR and AL participated in the formation of the final version of manuscript. All authors read and approved the final manuscript.

\section{Competing interests}

The authors declare that they have no competing interests.

Received: 8 April 2011 Accepted: 28 September 2011 Published: 28 September 2011

\section{References}

1. Ribeiro JM: Blood-feeding arthropods: live syringes or invertebrate pharmacologists? Infect Agents Dis 1995, 4:143-152.

2. Black WC: Evolution of arthropod disease vectors. In Emerging Pathogens. Edited by: Greenblatt C, Spigelman M. Oxford Biology; 2003:49-63.

3. Ribeiro JM, Francischetti IM: Role of arthropod saliva in blood feeding: sialome and post-sialome perspectives. Annu Rev Entomol 2003, 48:73-88.

4. Andrade BB, Teixeira CR, Barral A, Barral-Netto M: Haematophagous arthropod saliva and host defense system: a tale of tear and blood. An Acad Bras Cienc 2005, 77:665-693.

5. Francischetti IM, Sa-Nunes A, Mans BJ, Santos IM, Ribeiro JM: The role of saliva in tick feeding. Front Biosci 2009, 14:2051-2088.

6. Reunala T, Brummer-Korvenkontio H, Palosuo T: Are we really allergic to mosquito bites? Ann Med 1994, 26:301-306.

7. Bircher AJ: Systemic immediate allergic reactions to arthropod stings and bites. Dermatology 2005, 210:119-127.

8. Bellini R, Veronesi $R$, Draghetti S, Carrieri M: Study on the flying height of Aedes caspius and Culex pipiens females in the Po Delta area, Italy. J Am Mosa Control Assoc 1997, 13:356-360.

9. Balenghien T, Carron A, Sinegre G, Bicout DJ: Mosquito density forecast from flooding: population dynamics model for Aedes caspius (Pallas). Bull Entomol Res 2010, 100:247-254

10. Nuttall PA, Paesen GC, Lawrie $\mathrm{CH}$, Wang H: Vector-host interactions in disease transmission. J Mol Microbiol Biotechnol 2000, 2:381-386.

11. Rohousova I, Volf P: Sand fly saliva: effects on host immune response and Leishmania transmission. Folia Parasitol (Praha) 2006, 53:161-171.

12. WHO: Deaths by cause, sex and mortality stratum in WHO Regions, estimates for 2002. Geneva: World Health Organization; 2004 [http://www. who.int/whr/2004/annex/topic/annex2.xls]

13. Snow RW, Guerra CA, Noor AM, Myint HY, Hay Sl: The global distribution of clinical episodes of Plasmodium falciparum malaria. Nature 2005, 434:214-217.

14. Hotez PJ, Fenwick A, Savioli L, Molyneux DH: Rescuing the bottom billion through control of neglected tropical diseases. Lancet 2009, 373:1570-1575.

15. Campbell GL, Ceianu CS, Savage HM: Epidemic West Nile encephalitis in Romania: waiting for history to repeat itself. Ann N Y Acad Sci 2001, 951:94-101.

16. Kurkela S, Manni T, Myllynen J, Vaheri A, Vapalahti O: Clinical and laboratory manifestations of Sindbis virus infection: prospective study, Finland, 2002-2003. J Infect Dis 2005, 191:1820-1829.

17. Chastel C: [Lessons from the Greek dengue epidemic of 1927-1928]. Bull Acad Natl Med 2009, 193:485-493.

18. Barrett AD, Teuwen DE: Yellow fever vaccine - how does it work and why do rare cases of serious adverse events take place? Curr Opin Immunol 2009, 21:308-313.

19. Wilder-Smith A, Halstead S: Japanese encephalitis: update on vaccines and vaccine recommendations. Curr Opin Infect Dis 2010.

20. Ikegami T, Makino S: Rift valley fever vaccines. Vaccine 2009, 27(Suppl 4): D69-72.

21. Rendi-Wagner P: Advances in vaccination against tick-borne encephalitis. Expert Rev Vaccines 2008, 7:589-596.

22. Pradines B, Vial H, Olliaro P: [Malaria prophylaxis and treatment: problems, recent developments and perspectives]. Med Trop (Mars) 2003, 63:79-98.

23. Talbert A, Nyange A, Molteni F: Spraying tick-infested houses with lambda-cyhalothrin reduces the incidence of tick-borne relapsing fever in children under five years old. Trans R Soc Trop Med Hyg 1998, 92:251-253.

24. Alexander B, Maroli M: Control of phlebotomine sandflies. Med Vet Entomol 2003, 17:1-18.

25. WHO: Malaria Vector Control and Personal Protection. WHO Technical Report, Geneva, Switzerland 2006, No 936. 
26. Enayati A, Lines J, Maharaj R, Hemingway J: Shrinking the Malaria Map: A Prospectus on Malaria Elimination. Edited by Feachem RGA, Phillips $A A$, and Targett GA, San Francisco: The Global Health Group 2009, Chapter 9: Suppressing the Vector:140-154.

27. Nevill CG, Some ES, Mung'ala VO, Mutemi W, New L, Marsh K, Lengeler C, Snow RW: Insecticide-treated bednets reduce mortality and severe morbidity from malaria among children on the Kenyan coast. Trop Med Int Health 1996, 1:139-146.

28. Keiser J, Singer BH, Utzinger J: Reducing the burden of malaria in different eco-epidemiological settings with environmental management: a systematic review. Lancet Infect Dis 2005, 5:695-708.

29. Killeen GF, Smith TA, Ferguson HM, Mshinda H, Abdulla S, Lengeler C, Kachur SP: Preventing childhood malaria in Africa by protecting adults from mosquitoes with insecticide-treated nets. PLoS Med 2007, 4:e229.

30. Patterson R: Dr. William Gorgas and his war with the mosquito. CMA 1989, 141:596-597, 599

31. Killeen GF, Fillinger U, Kiche I, Gouagna LC, Knols BG: Eradication of Anopheles gambiae from Brazil: lessons for malaria control in Africa? Lancet Infect Dis 2002, 2:618-627.

32. Pennetier C, Corbel V, Boko P, Odjo A, N'Guessan R, Lapied B, Hougard JM: Synergy between repellents and non-pyrethroid insecticides strongly extends the efficacy of treated nets against Anopheles gambiae. Malar $J$ 2007, 6:38.

33. Malima RC, Magesa SM, Tungu PK, Mwingira V, Magogo FS, Sudi W, Mosha FW, Curtis CF, Maxwell C, Rowland M: An experimental hut evaluation of Olyset nets against anopheline mosquitoes after seven years use in Tanzanian villages. Malar J 2008, 7:38.

34. Kasili S, Kutima H, Mwandawiro C, Ngumbi PM, Anjili CO, Enayati AA: Laboratory and semi-field evaluation of long-lasting insecticidal nets against leishmaniasis vector, Phlebotomus (Phlebotomus) duboscai in Kenya. J Vector Borne Dis 2010, 47:1-10.

35. Tungu P, Magesa S, Maxwell C, Malima R, Masue D, Sudi W, Myamba J, Pigeon O, Rowland M: Evaluation of PermaNet 3.0 a deltamethrin-PBO combination net against Anopheles gambiae and pyrethroid resistant Culex quinquefasciatus mosquitoes: an experimental hut trial in Tanzania. Malar J 2010, 9:21.

36. Curtis CF, Mnzava AE: Comparison of house spraying and insecticidetreated nets for malaria control. Bull World Health Organ 2000, 78:1389-1400.

37. Lengeler $\mathrm{C}$ : Insecticide-treated bed nets and curtains for preventing malaria. Cochrane Database Syst Rev 2004, CD000363.

38. Killeen GF, McKenzie FE, Foy BD, Schieffelin C, Billingsley PF, Beier JC: The potential impact of integrated malaria transmission control on entomologic inoculation rate in highly endemic areas. Am J Trop Med Hyg 2000, 62:545-551.

39. Thavara U, Tawatsin A, Chompoosri J, Suwonkerd W, Chansang UR, Asavadachanukorn P: Laboratory and field evaluations of the insect repellent 3535 (ethyl butylacetylaminopropionate) and deet against mosquito vectors in Thailand. J Am Mosq Control Assoc 2001, 17:190-195

40. Mathenge EM, Misiani GO, Oulo DO, Irungu LW, Ndegwa PN, Smith TA, Killeen GF, Knols BG: Comparative performance of the Mbita trap, CDC light trap and the human landing catch in the sampling of Anopheles arabiensis, An. funestus and culicine species in a rice irrigation in western Kenya. Malar J 2005, 4:7.

41. Mbogo CM, Mwangangi JM, Nzovu J, Gu W, Yan G, Gunter JT, Swalm C, Keating J, Regens JL, Shililu Jl, et al: Spatial and temporal heterogeneity of Anopheles mosquitoes and Plasmodium falciparum transmission along the Kenyan coast. Am J Trop Med Hyg 2003, 68:734-742.

42. Orlandi-Pradines E, Rogier C, Koffi B, Jarjaval F, Bell M, Machault V, Pons C, Girod R, Boutin JP, Pages F: Major variations in malaria exposure of travellers in rural areas: an entomological cohort study in western Cote d'Ivoire. Malar J 2009, 8:171.

43. Cohnstaedt LW, Gillen Jl, Munstermann LE: Light-emitting diode technology improves insect trapping. J Am Mosq Control Assoc 2008, 24:331-334.

44. Carroll JF, Schmidtmann ET: Tick sweep: modification of the tick drag-flag method for sampling nymphs of the deer tick (Acari: Ixodidae). J Med Entomol 1992, 29:352-355.

45. Barral A, Honda E, Caldas A, Costa J, Vinhas V, Rowton ED, Valenzuela JG, Charlab R, Barral-Netto M, Ribeiro JM: Human immune response to sand fly salivary gland antigens: a useful epidemiological marker? Am J Trop Med Hyg 2000, 62:740-745.

46. Nascimento RJ, Santana JM, Lozzi SP, Araujo CN, Teixeira AR: Human IgG1 and IgG4: the main antibodies against Triatoma infestans (Hemiptera: Reduviidae) salivary gland proteins. Am J Trop Med Hyg 2001, 65:219-226.

47. Peng Z, Beckett AN, Engler RJ, Hoffman DR, Ott NL, Simons FE: Immune responses to mosquito saliva in 14 individuals with acute systemic allergic reactions to mosquito bites. J Allergy Clin Immunol 2004 114:1189-1194.

48. Remoue F, Cisse B, Ba F, Sokhna C, Herve JP, Boulanger D, Simondon F: Evaluation of the antibody response to Anopheles salivary antigens as a potential marker of risk of malaria. Trans R Soc Trop Med Hyg 2006, 100:363-370.

49. Orlandi-Pradines E, Almeras L, Denis de Senneville L, Barbe $S$, Remoue F, Villard C, Cornelie S, Penhoat K, Pascual A, Bourgouin C, et al: Antibody response against saliva antigens of Anopheles gambiae and Aedes aegypti in travellers in tropical Africa. Microbes Infect 2007, 9:1454-1462.

50. Poinsignon A, Remoue F, Rossignol M, Cornelie S, Courtin D, Grebaut $P$, Garcia A, Simondon F: Human IgG antibody response to Glossina saliva: an epidemiologic marker of exposure to Glossina bites. Am J Trop Med Hyg 2008, 78:750-753.

51. Wasinpiyamongkol L, Patramool S, Luplertlop N, Surasombatpattana P, Doucoure S, Mouchet F, Seveno M, Remoue F, Demettre E, Brizard JP, et al: Blood-feeding and immunogenic Aedes aegypti saliva proteins. Proteomics 2010, 10:1906-1916.

52. Ødegaard F: How many species of arthropods? Erwin's estimate revised. Biological Journal of the Linnean Society 2000, 71:583-597.

53. Adams TS: Hematophagy and Hormone Release. Annals of the Entomological Society of America 1999, 92:1-13.

54. Balashov YS: Evolution of Haematophagy in Insects and Ticks. Entomological review 1999, 79:943-954.

55. Black WC, Kondratieff BC: Evolution of arthropod disease vectors. Biology of disease vectors. 2 edition. Marquardt WC: Burilington, MA: Elsevier Academic Press; 2005

56. Lehane MJ: The Biology of Blood-Sucking in insects. Cambridge University Press; Second 2005

57. Chadee DD, Beier JC, Mohammed RT: Fast and slow blood-feeding durations of Aedes aegypti mosquitoes in Trinidad. J Vector Ecol 2002, 27:172-177.

58. Krober T, Guerin P: The tick blood meal: from a living animal or from a silicone membrane? ALTEX 2007, 24 Spec No:39-41.

59. Besansky NJ, Hill CA, Costantini C: No accounting for taste: host preference in malaria vectors. Trends Parasitol 2004, 20:249-251.

60. Johansson MA, Arana-Vizcarrondo N, Biggerstaff BJ, Staples JE: Incubation periods of Yellow fever virus. Am J Trop Med Hyg 2010, 83:183-188.

61. Prakash A, Bhattacharyya DR, Mohapatra PK, Mahanta J: Malaria transmission risk by the mosquito Anopheles baimaii (formerly known as An. dirus species D) at different hours of the night in North-east India. Med Vet Entomol 2005, 19:423-427.

62. Schofield CJ: Vector population responses to control interventions. Ann Soc Belg Med Trop 1991, 71(Suppl 1):201-217.

63. Wu KK, Thiagarajan P: Role of endothelium in thrombosis and hemostasis. Annu Rev Med 1996, 47:315-331.

64. Romney G, Glick M: An updated concept of coagulation with clinical implications. J Am Dent Assoc 2009, 140:567-574.

65. Ribeiro JM, Nussenzveig $\mathrm{RH}$ : The salivary catechol oxidase/peroxidase activities of the mosquito Anopheles albimanus. J Exp Biol 1993, 179:273-287.

66. Lerner EA, Ribeiro JM, Nelson RJ, Lerner MR: Isolation of maxadilan, a potent vasodilatory peptide from the salivary glands of the sand fly Lutzomyia longipalpis. J Biol Chem 1991, 266:11234-11236.

67. Cupp MS, Ribeiro JM, Champagne DE, Cupp EW: Analyses of cDNA and recombinant protein for a potent vasoactive protein in saliva of a blood-feeding black fly, Simulium vittatum. J Exp Biol 1998, 201:1553-1561.

68. Ribeiro JM, Katz O, Pannell LK, Waitumbi J, Warburg A: Salivary glands of the sand fly Phlebotomus papatasi contain pharmacologically active amounts of adenosine and 5'-AMP. J Exp Bio/ 1999, 202:1551-1559.

69. Cines DB, Pollak ES, Buck CA, Loscalzo J, Zimmerman GA, McEver RP, Pober JS, Wick TM, Konkle BA, Schwartz BS, et al: Endothelial cells in physiology and in the pathophysiology of vascular disorders. Blood 1998, 91:3527-3561. 
70. Ribeiro JM, Sarkis JJ, Rossignol PA, Spielman A: Salivary apyrase of Aedes aegypti: characterization and secretory fate. Comp Biochem Physiol B 1984, 79:81-86.

71. Sarkis JJ, Guimaraes JA, Ribeiro JM: Salivary apyrase of Rhodnius prolixus. Kinetics and purification. Biochem J 1986, 233:885-891.

72. Ribeiro JM, Vaughan JA, Azad AF: Characterization of the salivary apyrase activity of three rodent flea species. Comp Biochem Physiol B 1990 95:215-219.

73. Champagne DE, Smartt CT, Ribeiro JM, James AA: The salivary glandspecific apyrase of the mosquito Aedes aegypti is a member of the $5^{\prime}$ nucleotidase family. Proc Natl Acad Sci USA 1995, 92:694-698.

74. Marinotti $O$, de Brito M, Moreira CK: Apyrase and alpha-glucosidase in the salivary glands of Aedes albopictus. Comp Biochem Physiol B Biochem Mol Biol 1996, 113:675-679.

75. Mans BJ, Gaspar AR, Louw Al, Neitz AW: Apyrase activity and platelet aggregation inhibitors in the tick Ornithodoros savignyi (Acari: Argasidae). Exp Appl Acarol 1998, 22:353-366.

76. Valenzuela JG, Belkaid Y, Rowton E, Ribeiro JM: The salivary apyrase of the blood-sucking sand fly Phlebotomus papatasi belongs to the novel Cimex family of apyrases. J Exp Biol 2001, 204:229-237.

77. Faudry E, Lozzi SP, Santana JM, D'Souza-Ault M, Kieffer S, Felix CR, Ricart CA, Sousa MV, Vernet T, Teixeira AR: Triatoma infestans apyrases belong to the 5'-nucleotidase family. J Biol Chem 2004, 279:19607-19613.

78. Reno HE, Novak RJ: Characterization of apyrase-like activity in Ochlerotatus triseriatus, Ochlerotatus hendersoni, and Aedes aegypti. Am J Trop Med Hyg 2005, 73:541-545.

79. Hamasaki $R$, Kato $H$, Terayama $Y$, Iwata $H$, Valenzuela JG: Functional characterization of a salivary apyrase from the sand fly, Phlebotomus duboscai, a vector of Leishmania major. J Insect Physiol 2009, 55:1044-1049.

80. Francischetti IM, Ribeiro JM, Champagne D, Andersen J: Purification cloning, expression, and mechanism of action of a novel platelet aggregation inhibitor from the salivary gland of the blood-sucking bug, Rhodnius prolixus. J Biol Chem 2000, 275:12639-12650.

81. Troy GC: An overview of hemostasis. Vet Clin North Am Small Anim Pract 1988, 18:5-20.

82. Carmeliet P: Biomedicine. Clotting factors build blood vessels. Science 2001, 293:1602-1604

83. Levi $M$, ten Cate $H$, van der Poll T: Endothelium: interface between coagulation and inflammation. Crit Care Med 2002, 30:S220-224.

84. Isawa $H$, Yuda M, Orito $Y$, Chinzei $Y$ : A mosquito salivary protein inhibits activation of the plasma contact system by binding to factor XII and high molecular weight kininogen. J Biol Chem 2002, 277:27651-27658.

85. Isawa H, Orito Y, Iwanaga S, Jingushi N, Morita A, Chinzei Y, Yuda M: Identification and characterization of a new kallikrein-kinin system inhibitor from the salivary glands of the malaria vector mosquito Anopheles stephensi. Insect Biochem Mol Biol 2007, 37:466-477.

86. Canetti C, Silva JS, Ferreira SH, Cunha FQ: Tumour necrosis factor-alpha and leukotriene $B(4)$ mediate the neutrophil migration in immune inflammation. Br J Pharmacol 2001, 134:1619-1628.

87. Ramos CD, Canetti C, Souto JT, Silva JS, Hogaboam CM, Ferreira SH, Cunha FQ: MIP-1alpha[CCL3] acting on the CCR1 receptor mediates neutrophil migration in immune inflammation via sequential release of TNF-alpha and LTB4. J Leukoc Biol 2005, 78:167-177.

88. Chakravarti A, Allaeys I, Poubelle PE: [Neutrophils and immunity: is it innate or acquired?]. Med Sci (Paris) 2007, 23:862-867.

89. Valenzuela JG, Charlab R, Mather TN, Ribeiro JM: Purification, cloning, and expression of a novel salivary anticomplement protein from the tick, Ixodes scapularis. J Biol Chem 2000, 275:18717-18723.

90. Tyson K, Elkins C, Patterson H, Fikrig E, de Silva A: Biochemical and functional characterization of Salp20, an Ixodes scapularis tick salivary protein that inhibits the complement pathway. Insect Mol Biol 2007, 16:469-479.

91. Daix V, Schroeder H, Praet N, Georgin JP, Chiappino I, Gillet L, de Fays K, Decrem $Y$, Leboulle $G$, Godfroid $E$, et al: Ixodes ticks belonging to the Ixodes ricinus complex encode a family of anticomplement proteins. Insect Mol Biol 2007, 16:155-166.

92. Gwakisa P, Yoshihara K, Long To T, Gotoh H, Amano F, Momotani E: Salivary gland extract of Rhipicephalus appendiculatus ticks inhibits in vitro transcription and secretion of cytokines and production of nitric oxide by LPS-stimulated JA-4 cells. Vet Parasitol 2001, 99:53-61.
93. Kopecky J, Kuthejlova M: Suppressive effect of Ixodes ricinus salivary gland extract on mechanisms of natural immunity in vitro. Parasite Immunol 1998, 20:169-174.

94. Kubes M, Kocakova P, Slovak M, Slavikova M, Fuchsberger N, Nuttall PA: Heterogeneity in the effect of different ixodid tick species on human natural killer cell activity. Parasite Immunol 2002, 24:23-28.

95. Hovius JW, de Jong MA, den Dunnen J, Litjens M, Fikrig E, van der Poll T, Gringhuis SI, Geijtenbeek TB: Salp15 binding to DC-SIGN inhibits cytokine expression by impairing both nucleosome remodeling and mRNA stabilization. PLoS Pathog 2008, 4:e31

96. Salat J, Paesen GC, Rezacova P, Kotsyfakis M, Kovarova Z, Sanda M, Majtan J, Grunclova L, Horka H, Andersen JF, et al: Crystal structure and functional characterization of an immunomodulatory salivary cystatin from the soft tick Ornithodoros moubata. Biochem J 2010, 429:103-112.

97. Bissonnette EY, Rossignol PA, Befus AD: Extracts of mosquito salivary gland inhibit tumour necrosis factor alpha release from mast cells. Parasite Immunol 1993, 15:27-33.

98. Cavalcante RR, Pereira MH, Gontijo NF: Anti-complement activity in the saliva of phlebotomine sand flies and other haematophagous insects. Parasitology 2003, 127:87-93.

99. Sawynok J: Adenosine receptor activation and nociception. Eur J Pharmacol 1998, 347:1-11.

100. Charlab R, Rowton ED, Ribeiro JM: The salivary adenosine deaminase from the sand fly Lutzomyia longipalpis. Exp Parasitol 2000, 95:45-53.

101. Ribeiro JM, Charlab R, Valenzuela JG: The salivary adenosine deaminase activity of the mosquitoes Culex quinquefasciatus and Aedes aegypti. Exp Biol 2001, 204:2001-2010.

102. Mohamed TM: Adenosine deaminase from camel tick Hyalomma dromedarii: purification and characterization. Exp Appl Acarol 2006, 40:101-111.

103. Theodos CM, Titus RG: Salivary gland material from the sand fly Lutzomyia longipalpis has an inhibitory effect on macrophage function in vitro. Parasite Immunol 1993, 15:481-487.

104. Sa-Nunes A, Bafica A, Lucas DA, Conrads TP, Veenstra TD, Andersen JF, Mather TN, Ribeiro JM, Francischetti IM: Prostaglandin E2 is a major inhibitor of dendritic cell maturation and function in Ixodes scapularis saliva. J Immunol 2007, 179:1497-1505.

105. Skallova A, lezzi G, Ampenberger F, Kopf M, Kopecky J: Tick saliva inhibits dendritic cell migration, maturation, and function while promoting development of Th2 responses. J Immunol 2008, 180:6186-6192.

106. Nithiuthai S, Allen JR: Langerhans cells present tick antigens to lymph node cells from tick-sensitized guinea-pigs. Immunology 1985, 55:157-163.

107. Fearon DT, Locksley RM: The instructive role of innate immunity in the acquired immune response. Science 1996, 272:50-53.

108. Litman GW, Rast JP, Fugmann SD: The origins of vertebrate adaptive immunity. Nat Rev Immunol 2010, 10:543-553.

109. Ramachandra RN, Wikel SK: Modulation of host-immune responses by ticks (Acari: Ixodidae): effect of salivary gland extracts on host macrophages and lymphocyte cytokine production. J Med Entomol 1992, 29:818-826.

110. Urioste S, Hall LR, Telford SR, Titus RG: Saliva of the Lyme disease vector Ixodes dammini, blocks cell activation by a nonprostaglandin E2dependent mechanism. J Exp Med 1994, 180:1077-1085.

111. Cross ML, Cupp EW, Enriquez FJ: Differential modulation of murine cellular immune responses by salivary gland extract of Aedes aegypti. Am J Trop Med Hyg 1994, 51:690-696.

112. Wasserman HA, Singh S, Champagne DE: Saliva of the Yellow Fever mosquito, Aedes aegypti, modulates murine lymphocyte function. Parasite Immunol 2004, 26:295-306.

113. Brossard M, Wikel SK: Immunology of interactions between ticks and hosts. Med Vet Entomol 1997, 11:270-276.

114. Mbow ML, Bleyenberg JA, Hall LR, Titus RG: Phlebotomus papatasi sand fly salivary gland lysate down-regulates a Th1, but up-regulates a Th2, response in mice infected with Leishmania major. J Immunol 1998, 161:5571-5577.

115. Schoeler GB, Manweiler SA, Wikel SK: Ixodes scapularis: effects of repeated infestations with pathogen-free nymphs on macrophage and $T$ lymphocyte cytokine responses of $\mathrm{BALB} / \mathrm{C}$ and $\mathrm{C} 3 \mathrm{H} / \mathrm{HeN}$ mice. Exp Parasitol 1999, 92:239-248.

116. Caljon G, Van Den Abbeele J, Sternberg JM, Coosemans M, De Baetselier $P$, Magez S: Tsetse fly saliva biases the immune response to Th2 and 
induces anti-vector antibodies that are a useful tool for exposure assessment. Int J Parasitol 2006, 36:1025-1035.

117. Mejri N, Brossard M: Splenic dendritic cells pulsed with Ixodes ricinus tick saliva prime naive CD4+T to induce Th2 cell differentiation in vitro and in vivo. Int Immunol 2007, 19:535-543.

118. Titus RG, Ribeiro JM: Salivary gland lysates from the sand fly Lutzomyia longipalpis enhance Leishmania infectivity. Science 1988, 239:1306-1308.

119. Theodos CM, Ribeiro JM, Titus RG: Analysis of enhancing effect of sand fly saliva on Leishmania infection in mice. Infect Immun 1991, 59:1592-1598.

120. Bezerra HS, Teixeira MJ: Effect of Lutzomyia whitmani (Diptera: Psychodidae) salivary gland lysates on Leishmania (Viannia) braziliensis infection in BALB/c mice. Mem Inst Oswaldo Cruz 2001, 96:349-351.

121. Mesquita RD, Carneiro AB, Bafica A, Gazos-Lopes F, Takiya CM, SoutoPadron T, Vieira DP, Ferreira-Pereira A, Almeida IC, Figueiredo RT, et al: Trypanosoma cruzi infection is enhanced by vector saliva through immunosuppressant mechanisms mediated by lysophosphatidylcholine. Infect Immun 2008, 76:5543-5552.

122. Jones LD, Hodgson E, Williams T, Higgs S, Nuttall PA: Saliva activated transmission (SAT) of Thogoto virus: relationship with vector potential of different haematophagous arthropods. Med Vet Entomol 1992, 6:261-265.

123. Morris RV, Shoemaker CB, David JR, Lanzaro GC, Titus RG: Sandfly maxadilan exacerbates infection with Leishmania major and vaccinating against it protects against L. major infection. J Immunol 2001, 167:5226-5230.

124. Ramamoorthi N, Narasimhan S, Pal U, Bao F, Yang XF, Fish D, Anguita J, Norgard MV, Kantor FS, Anderson JF, et al: The Lyme disease agent exploits a tick protein to infect the mammalian host. Nature 2005, 436:573-577.

125. Rocha AC, Braga EM, Araujo MS, Franklin BS, Pimenta PF: Effect of the Aedes fluviatilis saliva on the development of Plasmodium gallinaceum infection in Gallus (gallus) domesticus. Mem Inst Oswaldo Cruz 2004, 99:709-715.

126. Thangamani S, Higgs S, Ziegler S, Vanlandingham D, Tesh R, Wikel S: Host immune response to mosquito-transmitted chikungunya virus differs from that elicited by needle inoculated virus. PLoS One 2010, 5:e12137.

127. Schneider BS, Soong L, Girard YA, Campbell G, Mason P, Higgs S: Potentiation of West Nile encephalitis by mosquito feeding. Viral Immunol 2006, 19:74-82.

128. Styer LM, Lim PY, Louie KL, Albright RG, Kramer LD, Bernard KA: Mosquito saliva causes enhancement of West Nile virus infection in mice. J Virol 2011, 85:1517-1527.

129. Osorio JE, Godsey MS, Defoliart GR, Yuill TM: La Crosse viremias in whitetailed deer and chipmunks exposed by injection or mosquito bite. Am J Trop Med Hyg 1996, 54:338-342.

130. Edwards JF, Higgs S, Beaty BJ: Mosquito feeding-induced enhancement of Cache Valley Virus (Bunyaviridae) infection in mice. J Med Entomol 1998, 35:261-265.

131. Vaughan JA, Scheller LF, Wirtz RA, Azad AF: Infectivity of Plasmodium berghei sporozoites delivered by intravenous inoculation versus mosquito bite: implications for sporozoite vaccine trials. Infect Immun 1999, 67:4285-4289.

132. Limesand KH, Higgs S, Pearson LD, Beaty BJ: Potentiation of vesicular stomatitis New Jersey virus infection in mice by mosquito saliva. Parasite Immunol 2000, 22:461-467.

133. Gillan V, Devaney E: Mosquito transmission modulates the immune response in mice infected with the $\mathrm{L} 3$ of Brugia pahangi. Parasite Immunol 2004, 26:359-363.

134. Theodor O: A study of the reaction to phlebotomus bites with some remarks on "Harara". Transactions of the Royal Society of Tropical Medicine and Hygiene 1935, 29:273-284.

135. Dubin YN, Reese JD, Seamans LA: Attempt to produce protection against mosquitoes by active immunization. J Immunol 1948, 58:293-297.

136. McKiel JA, West AS: Effects of repeated exposures of hypersensitive humans and laboratory rabbits to mosquito antigen. Canadian Journal of Zoology 1961, 39:597-603.

137. Wilson $A B$, Clements $A N$ : The Nature of the Skin Reaction to Mosquito Bites in Laboratory Animals. Int Arch Allergy Appl Immunol 1965, 26:294-314.

138. Ellis JA, Shapiro SZ, ole Moi-Yoi O, Moloo SK: Lesions and saliva-specific antibody responses in rabbits with immediate and delayed hypersensitivity reactions to the bites of Glossina morsitans centralis. Vet Pathol 1986, 23:661-667.

139. Chapman MD, Marshall NA, Saxon A: Identification and partial purification of species-specific allergens from Triatoma protracta (Heteroptera: Reduviidae). J Allergy Clin Immunol 1986, 78:436-442.

140. Shen HD, Chen CC, Chang HN, Chang LY, Tu WC, Han SH: Human IgE and IgG antibodies to mosquito proteins detected by the immunoblot technique. Ann Allergy 1989, 63:143-146.

141. Gauci M, Stone BF, Thong YH: Isolation and immunological characterisation of allergens from salivary glands of the Australian paralysis tick Ixodes holocyclus. Int Arch Allergy Appl Immunol 1988, 87:208-212.

142. Wongkamchai S, Khongtak P, Leemingsawat S, Komalamisra N, Junsong N, Kulthanan K, Wisuthsarewong W, Boitano JJ: Comparative identification of protein profiles and major allergens of saliva, salivary gland and whole body extracts of mosquito species in Thailand. Asian Pac J Allergy Immunol 2010, 28:162-169.

143. Almeras L, Fontaine A, Belghazi M, Bourdon S, Boucomont-Chapeaublanc $E_{\text {, }}$ Orlandi-Pradines E, Baragatti M, Corre-Catelin N, Reiter P, Pradines B, et al: Salivary gland protein repertoire from Aedes aegypti mosquitoes. Vector Borne Zoonotic Dis 2010, 10:391-402.

144. Brummer-Korvenkontio H, Lappalainen P, Reunala T, Palosuo T: Detection of mosquito saliva-specific lgE and lgG4 antibodies by immunoblotting. J Allergy Clin Immunol 1994, 93:551-555.

145. Brummer-Korvenkontio H, Palosuo K, Palosuo T, Brummer-Korvenkontio M, Leinikki $P$, Reunala T: Detection of mosquito saliva-specific IgE antibodies by capture ELISA. Allergy 1997, 52:342-345.

146. Peng Z, Simons FE: Cross-reactivity of skin and serum specific lgE responses and allergen analysis for three mosquito species with worldwide distribution. J Allergy Clin Immunol 1997, 100:192-198.

147. Jeon SH, Park JW, Lee BH: Characterization of human IgE and mouse $\lg \mathrm{G} 1$ responses to allergens in three mosquito species by immunoblotting and ELISA. Int Arch Allergy Immunol 2001, 126:206-212

148. Cornelie S, Remoue F, Doucoure S, Ndiaye T, Sauvage FX, Boulanger D, Simondon F: An insight into immunogenic salivary proteins of Anopheles gambiae in African children. Malar J 2007, 6:75.

149. Parmar A, Grewal AS, Dhillon P: Immunological cross-reactivity between salivary gland proteins of Hyalomma anatolicum anatolicum and Boophilus microplus ticks. Vet Immunol Immunopathol 1996, 51:345-352.

150. Marshall NA, Chapman MD, Saxon A: Species-specific allergens from the salivary glands of Triatominae (Heteroptera:Reduviidae). J Allergy Clin Immunol 1986, 78:430-435.

151. Peng Z, Xu W, James AA, Lam H, Sun D, Cheng L, Simons FE: Expression, purification, characterization and clinical relevance of rAed a $1-\mathrm{a} 68-\mathrm{kDa}$ recombinant mosquito Aedes aegypti salivary allergen. Int Immunol 2001, 13:1445-1452.

152. Peng $Z$, Xu W, Lam $H$, Cheng $L$, James $A A$, Simons FE: A new recombinant mosquito salivary allergen, rAed a 2: allergenicity, clinical relevance, and cross-reactivity. Allergy 2006, 61:485-490.

153. Beaudouin E, Kanny G, Renaudin JM, Moneret-Vautrin DA: Allergen-specific immunotherapy to mosquitoes. Allergy 2001, 56:787

154. Ariano R, Panzani RC: Efficacy and safety of specific immunotherapy to mosquito bites. Eur Ann Allergy Clin Immunol 2004, 36:131-138.

155. Peng Z, Simons FE: Comparison of proteins, IgE, and IgG binding antigens, and skin reactivity in commercial and laboratory-made mosquito extracts. Ann Allergy Asthma Immunol 1996, 77:371-376.

156. Bell JF, Stewart SJ, Wikel SK: Resistance to tick-borne Francisella tularensis by tick-sensitized rabbits: allergic klendusity. Am J Trop Med Hyg 1979, 28:876-880.

157. Wikel SK, Ramachandra RN, Bergman DK, Burkot TR, Piesman J: Infestation with pathogen-free nymphs of the tick Ixodes scapularis induces host resistance to transmission of Borrelia burgdorferi by ticks. Infect Immun 1997, 65:335-338.

158. Belkaid Y, Kamhawi S, Modi G, Valenzuela J, Noben-Trauth N, Rowton E, Ribeiro J, Sacks DL: Development of a natural model of cutaneous leishmaniasis: powerful effects of vector saliva and saliva preexposure on the long-term outcome of Leishmania major infection in the mouse ear dermis. J Exp Med 1998, 188:1941-1953.

159. Donovan MJ, Messmore AS, Scrafford DA, Sacks DL, Kamhawi S, McDowell MA: Uninfected mosquito bites confer protection against infection with malaria parasites. Infect Immun 2007, 75:2523-2530. 
160. Kebaier C, Voza T, Vanderberg J: Neither mosquito saliva nor immunity to saliva has a detectable effect on the infectivity of Plasmodium sporozoites injected into mice. Infect Immun 2010, 78:545-551.

161. Valenzuela JG, Belkaid Y, Garfield MK, Mendez S, Kamhawi S, Rowton ED, Sacks DL, Ribeiro JM: Toward a defined anti-Leishmania vaccine targeting vector antigens: characterization of a protective salivary protein. J Exp Med 2001, 194:331-342.

162. Oliveira F, Lawyer PG, Kamhawi S, Valenzuela JG: Immunity to distinct sand fly salivary proteins primes the anti-Leishmania immune response towards protection or exacerbation of disease. PLoS Negl Trop Dis 2008, 2: e226.

163. Dai J, Wang P, Adusumilli S, Booth CJ, Narasimhan S, Anguita J, Fikrig E: Antibodies against a tick protein, Salp15, protect mice from the Lyme disease agent. Cell Host Microbe 2009, 6:482-492.

164. Steere AC, Sikand VK, Meurice F, Parenti DL, Fikrig E, Schoen RT, Nowakowski J, Schmid CH, Laukamp S, Buscarino C, Krause DS: Vaccination against Lyme disease with recombinant Borrelia burgdorferi outer-surface lipoprotein A with adjuvant. Lyme Disease Vaccine Study Group. N Engl J Med 1998, 339:209-215.

165. Schneider BS, Mathieu C, Peronet R, Mecheri S: Anopheles stephensi saliva enhances progression of cerebral malaria in a murine model. Vector Borne Zoonotic Dis 2011, 11:423-432.

166. Ballou WR: The development of the RTS, S malaria vaccine candidate: challenges and lessons. Parasite Immunol 2009, 31:492-500.

167. Dodoo D, Atuguba F, Bosomprah S, Ansah NA, Ansah P, Lamptey H, Egyir B, Oduro AR, Gyan B, Hodgson A, Koram KA: Antibody levels to multiple malaria vaccine candidate antigens in relation to clinical malaria episodes in children in the Kasena-Nankana district of Northern Ghana. Malar J 2011, 10:108

168. Mulenga A, Sugimoto C, Sako Y, Ohashi K, Musoke A, Shubash M, Onuma M: Molecular characterization of a Haemaphysalis longicornis tick salivary gland-associated 29-kilodalton protein and its effect as a vaccine against tick infestation in rabbits. Infect Immun 1999, 67:1652-1658.

169. Prevot PP, Couvreur B, Denis V, Brossard M, Vanhamme L, Godfroid E: Protective immunity against Ixodes ricinus induced by a salivary serpin. Vaccine 2007, 25:3284-3292.

170. Garcia-Varas S, Manzano-Roman R, Fernandez-Soto P, Encinas-Grandes A, Oleaga A, Perez-Sanchez R: Purification and characterisation of a Pselectin-binding molecule from the salivary glands of Ornithodoros moubata that induces protective anti-tick immune responses in pigs. Int J Parasitol 2009, 40:313-326.

171. de la Fuente J, Kocan KM: Advances in the identification and characterization of protective antigens for recombinant vaccines against tick infestations. Expert Rev Vaccines 2003, 2:583-593.

172. Labuda M, Trimnell AR, Lickova M, Kazimirova M, Davies GM, Lissina O, Hails RS, Nuttall PA: An antivector vaccine protects against a lethal vector-borne pathogen. PLoS Pathog 2006, 2:e27.

173. de la Fuente J, Almazan C, Canales M, Perez de la Lastra JM, Kocan KM, Willadsen P: A ten-year review of commercial vaccine performance for control of tick infestations on cattle. Anim Health Res Rev 2007, 8:23-28.

174. Chugh M, Adak T, Sehrawat N, Gakhar SK: Effect of anti-mosquito midgut antibodies on development of malaria parasite, Plasmodium vivax and fecundity in vector mosquito Anopheles culicifacies (Diptera: culicidae). Indian J Exp Biol 2011, 49:245-253.

175. Farrance CE, Rhee A, Jones RM, Musiychuk K, Shamloul M, Sharma S, Mett V, Chichester JA, Streatfield SJ, Roeffen W, et al: A Plant-Produced Pfs230 Vaccine Candidate Blocks Transmission of Plasmodium falciparum. Clin Vaccine Immunol 2011.

176. Reunala T, Brummer-Korvenkontio H, Palosuo K, Miyanij M, RuizMaldonado R, Love A, Francois G, Palosuo T: Frequent occurrence of IgE and IgG4 antibodies against saliva of Aedes communis and Aedes aegypti mosquitoes in children. Int Arch Allergy Immunol 1994, 104:366-371.

177. Wilson AD, Harwood LJ, Bjornsdottir S, Marti E, Day MJ: Detection of IgG and IgE serum antibodies to Culicoides salivary gland antigens in horses with insect dermal hypersensitivity (sweet itch). Equine Vet J 2001, 33:707-713.

178. Peng Z, Li H, Simons FE: Immunoblot analysis of IgE and IgG binding antigens in extracts of mosquitos Aedes vexans, Culex tarsalis and Culiseta inornata. Int Arch Allergy Immunol 1996, 110:46-51.
179. Abdel-Naser MB, Lotfy RA, Al-Sherbiny MM, Sayed Ali NM: Patients with papular urticaria have IgG antibodies to bedbug (Cimex lectularius) antigens. Parasitol Res 2006, 98:550-556.

180. Schwartz BS, Ribeiro JM, Goldstein MD: Anti-tick antibodies: an epidemiologic tool in Lyme disease research. Am J Epidemiol 1990, 132:58-66.

181. Palosuo K, Brummer-Korvenkontio H, Mikkola J, Sahi T, Reunala T: Seasonal increase in human $\operatorname{lgE}$ and $\lg G 4$ antisaliva antibodies to Aedes mosquito bites. Int Arch Allergy Immunol 1997, 114:367-372.

182. Peng Z, Rasic N, Liu Y, Simons FE: Mosquito saliva-specific lgE and IgG antibodies in 1059 blood donors. J Allergy Clin Immunol 2002, 110:816-817.

183. Schwarz A, Medrano-Mercado N, Billingsley PF, Schaub GA, Sternberg JM: IgM-antibody responses of chickens to salivary antigens of Triatoma infestans as early biomarkers for low-level infestation of triatomines. Int J Parasitol 2010, 40:1295-1302.

184. Billingsley PF, Baird J, Mitchell JA, Drakeley C: Immune interactions between mosquitoes and their hosts. Parasite Immunol 2006, 28:143-153.

185. Shililu JI, Maier WA, Seitz HM, Orago AS: Seasonal density, sporozoite rates and entomological inoculation rates of Anopheles gambiae and Anopheles funestus in a high-altitude sugarcane growing zone in Western Kenya. Trop Med Int Health 1998, 3:706-710.

186. Doolan DL, Dobano C, Baird JK: Acquired immunity to malaria. Clin Microbiol Rev 2009, 22:13-36, Table of Contents.

187. Drame PM, Poinsignon A, Besnard P, Le Mire J, Dos-Santos MA, Sow CS, Cornelie S, Foumane V, Toto JC, Sembene M, et al: Human antibody response to Anopheles gambiae saliva: an immuno-epidemiological biomarker to evaluate the efficacy of insecticide-treated nets in malaria vector control. Am J Trop Med Hyg 2010, 83:115-121.

188. Schwarz A, Juarez JA, Richards J, Rath B, Machaca VQ, Castro YE, Malaga ES, Levy K, Gilman RH, Bern C, et al: Anti-triatomine saliva immunoassays for the evaluation of impregnated netting trials against Chagas disease transmission. Int J Parasitol 2011, 41:591-594.

189. Balenghien T, Fouque F, Sabatier P, Bicout DJ: Horse-, bird-, and humanseeking behavior and seasonal abundance of mosquitoes in a West Nile virus focus of southern France. J Med Entomol 2006, 43:936-946.

190. Toprak S, Ozer N: Distribution of sand fly (Diptera: Psychodidae) species and efficiency of capturing methods in Sanliurfa province, Turkey. J Med Entomol 2007, 44:23-28.

191. Wheeler CM, Coleman JL, Benach JL: Salivary gland antigens of Ixodes dammini are glycoproteins that have interspecies cross-reactivity. J Parasitol 1991, 77:965-973.

192. Trevejo RT, Reisen WK, Yoshimura G, Reeves WC: Detection of chicken antibodies to mosquito salivary gland antigens by enzyme immunoassay. J Am Mosa Control Assoc 2005, 21:39-48.

193. Pinnas JL, Lindberg RE, Chen TM, Meinke GC: Studies of kissing bugsensitive patients: evidence for the lack of cross-reactivity between Triatoma protracta and Triatoma rubida salivary gland extracts. J Allergy Clin Immunol 1986, 77:364-370.

194. Volf P, Rohousova I: Species-specific antigens in salivary glands of phlebotomine sandflies. Parasitology 2001, 122 Pt 1:37-41.

195. Rohousova I, Ozensoy S, Ozbel Y, Volf P: Detection of species-specific antibody response of humans and mice bitten by sand flies. Parasitology 2005, 130:493-499.

196. Arensburger P, Megy K, Waterhouse RM, Abrudan J, Amedeo P, Antelo B, Bartholomay L, Bidwell S, Caler E, Camara F, et al: Sequencing of Culex quinquefasciatus establishes a platform for mosquito comparative genomics. Science 2010, 330:86-88.

197. Holt RA, Subramanian GM, Halpern A, Sutton GG, Charlab R, Nusskern DR, Wincker P, Clark AG, Ribeiro JM, Wides R, et al: The genome sequence of the malaria mosquito Anopheles gambiae. Science 2002, 298:129-149.

198. Mongin E, Louis C, Holt RA, Birney E, Collins FH: The Anopheles gambiae genome: an update. Trends Parasitol 2004, 20:49-52.

199. Hill CA, Wikel SK: The Ixodes scapularis Genome Project: an opportunity for advancing tick research. Trends Parasitol 2005, 21:151-153.

200. Nene V, Wortman JR, Lawson D, Haas B, Kodira C, Tu ZJ, Loftus B, Xi Z, Megy K, Grabherr M, et al: Genome sequence of Aedes aegypti, a major arbovirus vector. Science 2007, 316:1718-1723.

201. Arca B, Lombardo F, Valenzuela JG, Francischetti IM, Marinotti O, Coluzzi M, Ribeiro JM: An updated catalogue of salivary gland transcripts in the 
adult female mosquito, Anopheles gambiae. J Exp Biol 2005, 208:3971-3986.

202. Santos A, Ribeiro JM, Lehane MJ, Gontijo NF, Veloso AB, Sant'Anna MR, Nascimento Araujo R, Grisard EC, Pereira MH: The sialotranscriptome of the blood-sucking bug Triatoma brasiliensis (Hemiptera, Triatominae). Insect Biochem Mol Biol 2007, 37:702-712.

203. Arca B, Lombardo F, Francischetti IM, Pham VM, Mestres-Simon M, Andersen JF, Ribeiro JM: An insight into the sialome of the adult female mosquito Aedes albopictus. Insect Biochem Mol Biol 2007, 37:107-127.

204. Calvo E, Pham VM, Marinotti O, Andersen JF, Ribeiro JM: The salivary gland transcriptome of the neotropical malaria vector Anopheles darlingi reveals accelerated evolution of genes relevant to hematophagy. BMC Genomics 2009, 10:57.

205. Ribeiro JMC, Mans BJ, Arcà B: An insight into the sialome of bloodfeeding Nematocera. Insect Biochemistry and Molecular Biology 2010, 40:767-784.

206. Calvo E, Sanchez-Vargas I, Favreau AJ, Barbian KD, Pham VM, Olson KE, Ribeiro JM: An insight into the sialotranscriptome of the West Nile mosquito vector, Culex tarsalis. BMC Genomics 2010, 11:51.

207. Anatriello E, Ribeiro JM, de Miranda Santos IK, Brandao LG, Anderson JM, Valenzuela JG, Maruyama SR, Silva JS, Ferreira BR: An insight into the sialotranscriptome of the brown dog tick, Rhipicephalus sanguineus. BMC Genomics 2010, 11:450.

208. Alves-Silva J, Ribeiro JM, Van Den Abbeele J, Attardo G, Hao Z, Haines LR, Soares MB, Berriman M, Aksoy S, Lehane MJ: An insight into the sialome of Glossina morsitans morsitans. BMC Genomics 2010, 11:213.

209. Calvo E, Dao A, Pham VM, Ribeiro JM: An insight into the sialome of Anopheles funestus reveals an emerging pattern in anopheline salivary protein families. Insect Biochem Mol Biol 2007, 37:164-175.

210. Almeras L, Orlandi-Pradines E, Fontaine A, Villard C, Boucomont E, de Senneville LD, Baragatti M, Pascual A, Pradines B, Corre-Catelin N, et al: Sialome individuality between Aedes aegypti colonies. Vector Borne Zoonotic Dis 2009, 9:531-541.

211. Ben Hadj Ahmed S, Kaabi B, Chelbi I, Cherni S, Derbali M, Laouini D, Zhioua E: Colonization of Phlebotomus papatasi changes the effect of pre-immunization with saliva from lack of protection towards protection against experimental challenge with Leishmania major and saliva. Parasit Vectors 2011, 4:126.

212. Laurenti MD, da Matta VL, Pernichelli T, Secundino NF, Pinto LC, Corbett CE, Pimenta PP: Effects of salivary gland homogenate from wild-caught and laboratory-reared Lutzomyia longipalpis on the evolution and immunomodulation of Leishmania (Leishmania) amazonensis infection. Scand I Immunol 2009, 70:389-395.

213. Fontaine A, Pascual A, Diouf I, Bakkali N, Bourdon S, Fusai T, Rogier C, Almeras L: Mosquito salivary gland protein preservation in the field for immunological and biochemical analysis. Parasit Vectors 2011, 4:33.

214. Volf $P$, Tesarova $P$, Nohynkova EN: Salivary proteins and glycoproteins in phlebotomine sandflies of various species, sex and age. Med Vet Entomol 2000, 14:251-256.

215. Choumet V, Carmi-Leroy A, Laurent C, Lenormand P, Rousselle JC, Namane A, Roth C, Brey PT: The salivary glands and saliva of Anopheles gambiae as an essential step in the Plasmodium life cycle: a global proteomic study. Proteomics 2007, 7:3384-3394.

216. Prates DB, Santos LD, Miranda JC, Souza AP, Palma MS, Barral-Netto M, Barral A: Changes in amounts of total salivary gland proteins of Lutzomyia longipallpis (Diptera: Psychodidae) according to age and diet. J Med Entomol 2008, 45:409-413.

217. Lombardo F, Ronca R, Rizzo C, Mestres-Simon M, Lanfrancotti A, Curra C, Fiorentino G, Bourgouin C, Ribeiro JM, Petrarca V, et al: The Anopheles gambiae salivary protein gSG6: an anopheline-specific protein with a blood-feeding role. Insect Biochem Mol Biol 2009, 39:457-466.

218. Poinsignon A, Cornelie S, Mestres-Simon M, Lanfrancotti A, Rossignol M, Boulanger D, Cisse B, Sokhna C, Arca B, Simondon F, Remoue F: Novel peptide marker corresponding to salivary protein gSG6 potentially identifies exposure to Anopheles bites. PLoS One 2008, 3:e2472.

219. Rizzo C, Ronca R, Fiorentino G, Verra F, Mangano V, Poinsignon A, Sirima SB, Nebie I, Lombardo F, Remoue F, et al: Humoral response to the Anopheles gambiae salivary protein gSG6: a serological indicator of exposure to Afrotropical malaria vectors. PLOS One 2011, 6:e17980

220. Poinsignon A, Samb B, Doucoure S, Drame PM, Sarr JB, Sow C, Cornelie S, Maiga S, Thiam C, Rogerie F, et al: First attempt to validate the gSG6-P1 salivary peptide as an immuno-epidemiological tool for evaluating human exposure to Anopheles funestus bites. Trop Med Int Health 2010, 15:1198-1203.

221. Sanders ML, Jaworski DC, Sanchez UL, DeFraites RF, Glass GE, Scott AL, Raha S, Ritchie BC, Needham GR, Schwartz BS: Antibody to a cDNAderived calreticulin protein from Amblyomma americanum as a biomarker of tick exposure in humans. Am J Trop Med Hyg 1998, 59:279-285.

222. Sanders ML, Glass GE, Nadelman RB, Wormser GP, Scott AL, Raha S, Ritchie BC, Jaworski DC, Schwartz BS: Antibody levels to recombinant tick calreticulin increase in humans after exposure to lxodes scapularis (Say) and are correlated with tick engorgement indices. Am J Epidemiol 1999, 149:777-784.

223. Teixeira C, Gomes R, Collin N, Reynoso D, Jochim R, Oliveira F, Seitz A, Elnaiem DE, Caldas A, de Souza AP, et al: Discovery of markers of exposure specific to bites of Lutzomyia longipalpis, the vector of Leishmania infantum chagasi in Latin America. PLoS Negl Trop Dis 2010, 4: e638.

224. Souza AP, Andrade BB, Aquino D, Entringer P, Miranda JC, Alcantara R, Ruiz D, Soto M, Teixeira CR, Valenzuela JG, et al: Using recombinant proteins from Lutzomyia longipalpis saliva to estimate human vector exposure in visceral Leishmaniasis endemic areas. PLoS Negl Trop Dis 2010, 4:e649.

225. Paddock CD, McKerrow JH, Hansell E, Foreman KW, Hsieh I, Marshall N: Identification, cloning, and recombinant expression of procalin, a major triatomine allergen. J Immunol 2001, 167:2694-2699.

226. Horackova J, Rudenko N, Golovchenko M, Grubhoffer L: Der-p2 (Dermatophagoides pteronyssinus) allergen-like protein from the hard tick Ixodes ricinus - a novel member of ML (MD-2-related lipidrecognition) domain protein family. Parasitology 2010, 137:1139-1149.

227. Hilger C, Bessot JC, Hutt N, Grigioni F, De Blay F, Pauli G, Hentges F: IgEmediated anaphylaxis caused by bites of the pigeon tick Argas reflexus: cloning and expression of the major allergen Arg r 1. J Allergy Clin Immunol 2005, 115:617-622.

228. Caljon G, Broos K, De Goeyse I, De Ridder K, Sternberg JM, Coosemans M, De Baetselier P, Guisez Y, Den Abbeele JV: Identification of a functional Antigen5-related allergen in the saliva of a blood feeding insect, the tsetse fly. Insect Biochem Mol Biol 2009, 39:332-341.

229. Gomes R, Teixeira C, Teixeira MJ, Oliveira F, Menezes MJ, Silva C, de Oliveira Cl, Miranda JC, Elnaiem DE, Kamhawi S, et al: Immunity to a salivary protein of a sand fly vector protects against the fatal outcome of visceral leishmaniasis in a hamster model. Proc Natl Acad Sci USA 2008, 105:7845-7850.

230. Poinsignon A, Cornelie S, Ba F, Boulanger D, Sow C, Rossignol M, Sokhna C, Cisse $B$, Simondon F, Remoue F: Human IgG response to a salivary peptide, gSG6-P1, as a new immuno-epidemiological tool for evaluating low-level exposure to Anopheles bites. Malar J 2009, 8:198.

231. Pickering JW, Martins TB, Schroder MC, Hill HR: Comparison of a multiplex flow cytometric assay with enzyme-linked immunosorbent assay for auantitation of antibodies to tetanus, diphtheria, and Haemophilus influenzae Type b. Clin Diagn Lab Immunol 2002, 9:872-876.

232. Lal G, Balmer P, Joseph H, Dawson M, Borrow R: Development and evaluation of a tetraplex flow cytometric assay for quantitation of serum antibodies to Neisseria meningitidis serogroups A, C, Y, and W-135. Clin Diagn Lab Immunol 2004, 11:272-279.

233. Ambrosino E, Dumoulin C, Orlandi-Pradines E, Remoue F, Toure-Balde A, Tall A, Sarr JB, Poinsignon A, Sokhna C, Puget K, et al: A multiplex assay for the simultaneous detection of antibodies against 15 Plasmodium falciparum and Anopheles gambiae saliva antigens. Malar J 2010, 9:317.

\section{doi:10.1186/1756-3305-4-187}

Cite this article as: Fontaine et al:: Implication of haematophagous arthropod salivary proteins in host-vector interactions. Parasites \& Vectors 2011 4:187. 